\title{
On the 50-year research landscape of entrepreneurial finance: A sign of Western ideological homogeneity?
}

\author{
Minh-Hoang Nguyen ${ }^{1, *}$ \\ Huyen Thanh T. Nguyen ${ }^{2}$ \\ Thanh-Hang Pham ${ }^{3,4}$ \\ Quynh-Yen Thi Nguyen ${ }^{5}$ \\ Quan-Hoang Vuong 1,6
}

1 Centre for Interdisciplinary Social Research, Phenikaa University, Yen Nghia Ward, Ha Dong District, Hanoi 100803, Vietnam; hoang.nguyenminh@phenikaa-uni.edu.vn, hoang.vuongquan@phenikaa-uni.edu.vn

2 School of Economics and International Business, Foreign Trade University, 91 Chua Lang, Dong Da, Hanoi; huyen.ngtt98@gmail.com

3 Faculty of Management and Tourism, Hanoi University, Km9, Nguyen Trai Road, Thanh Xuan, Hanoi

100803, Vietnam; hangpt@hanu.edu.vn

4 School of Business, RMIT Vietnam University, Hanoi, 100000, Viet Nam

5 College of Asia Pacific Studies, Ritsumeikan Asia Pacific University, Beppu, Oita 8748577, Japan; thiqng17@apu.ac.jp

6 Centre Emile Bernheim, Universite Libre de Bruxelles, Brussels B-1050, Belgium; qvuong@ulb.ac.be

* Correspondence: hoang.nguyenminh @ phenikaa-uni.edu.vn

Abstract: Financing issues play essential roles in the survival and development of entrepreneurial firms. The current study, employing the bibliometric analysis of 6,903 articles from 1970 to 2019, extracted from Web of Science database, aims to provide an overview of the discipline's landscape and major scientific domains to facilitate scientific development within the field. Entrepreneurial finance is a young and growing field with exponential growth in the number of publications (with $19.54 \%$ per year) and rising collaboration tendency among authors. Journal of Business Venturing is the most prestigious journal, while Sustainability is noteworthy for its rapid contribution to the field. We also note a sign of Western ideological homogeneity from the collaboration networks and lists of top authors, institutions, and countries. Besides, using keyword co-occurrence analysis, seven major research domains are identified: "venture capital", "crowdfunding", "SMEs finance", "social entrepreneurship finance", "financial risk", "microfinance", and "human-social-financial capital". Based on these findings, we raise the concern of lacking diversity in entrepreneurial finance research and provide several recommendations for future potential research directions.

Keywords: entrepreneurial finance; bibliometrics; Western; ideological homogeneity; crowdfunding; microfinance; social entrepreneurship 


\section{Working Paper ISR-JFRM1 \#20-05}

(This version: v.4; May 28, 2020)

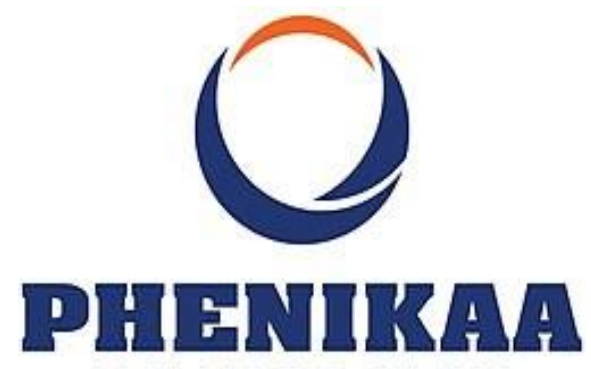

UNIVERSIT Y

Centre for Interdisciplinary Social Research; Phenikaa University To Huu, Ha Dong District, Hanoi 100803, Vietnam 


\section{Introduction}

New companies play a crucial role in economic, social, and environmental sustainability across the globe. According to the statistics of the Organization for Economic Cooperation and Development (OECD), firm start-ups and small and medium enterprises (SMEs) contribute to 99\% of all businesses and around 50\%-60\% of added value (OECD 2017, 2019). Regarding developed countries, for example in the United States (US) job market, startups are among major job creators, even though their impact on net job creation is not sustainable because more than half of them fail in the first five years (Dilger 2013, Gompers and Lerner 1994). Also, small startups play a significant role in fostering innovation by reducing bureaucratic inertia and resistance to new R\&D, which is one of the crucial factors that lead to economic growth (Megginson 2002, Napier et al. 2012, Scherer 1991, Vu et al. 2013, Vuong et al. 2011). For developing nations, newly established businesses are expected to drive economic development without compromising the future of the social and environmental aspects in both the short and long term (Dhahri and Omri 2018, Vuong et al. 2020).

For entrepreneurial companies, these firms often require substantial amounts of financial capital to sustain their development; consequently, one of the most crucial matters is their ability to access capital (Bellavitis et al. 2017, Denis 2004). Therefore, the discipline of entrepreneurial finance research was born to investigate this important issue. By definition, entrepreneurial finance focuses on studying the financial aspects of entrepreneurship, such as financial performance and resource allocation, etc., which is deviated from traditional finance studies (Paré et al. 2009). Research in this discipline was almost non-existent until the early 1990s; however, it is stated that this is a rapidly growing research field, and "the volume of academic research in entrepreneurial finance is catching up with the volume of financing activity in this sector of the economy" (Denis 2004).

The state of the art of entrepreneurial finance has recently been examined by several scientists; to mention a few, studies of Bellavitis et al. and Cumming et al. are great examples. Bellavitis et al. (2017) provide knowledge of current emerging sources of finance and generally forgotten sources of finance as well as the insufficiencies of mainstream theories in the entrepreneurial context. They also suggest that future attention should be paid to new sources of entrepreneurial funding (e.g., crowdfunding), usually ignored conventional financing sources (e.g., bank debt), and the globalization of entrepreneurial finance markets. Cumming et al. (2019a) summarize recent advances in the literature regarding the financing of entrepreneurial firms during their lifecycle, the effect of business angels on newly established firms' economic performance, and how entrepreneurs finance from venture capital finance. Based on the summary, the authors recommend future research to examine the international flows of funding given the development of internetbased financing platform (like crowdfunding), the interplay between different types of investors given that financing sources (e.g., crowdfunding, business angel, venture capitalists, etc.) as complements or substitutes for each other, and the sustainability as well as social-human capital of board members.

These studies, together with others such as (Chemmanur and Fulghieri 2014, Cumming and Groh 2018, Fraser et al. 2015), provide relatively comprehensive and detailed research trends. However, they all use qualitative analysis, which is subjective in nature and significantly influenced by prior knowledge of researchers. Moreover, these works merely focus on some facets of entrepreneurial 
finance research. The current body of literature in this discipline, despite its significant growth over the last few decades, has not provided an overview landscape of this research area. As a result, this study aims to fill this gap by using bibliometrics, which has been widely applied to help researchers assess the discipline's landscape, and governments/funding organizations optimize the efficiency and effectiveness of research and funding allocation (Moed 2006, Weingart 2005). For example, bibliometric analysis has been used in articles to provide an overview of the current state of research in entrepreneurship education (Aparicio et al. 2019), social entrepreneurship (Kraus et al. 2014), ethics in entrepreneurship (Vallaster et al. 2019), financing innovation (Padilla-Ospina et al. 2018), and the Global Finance Journal (Baker et al. 2019). The increasing popularity of this statistical method is consequential from its advantages, including large-scale applicability, easy replicability, and perceived objectivity (Haustein and Larivière 2015). In particular, compared to traditional methods to conduct literature reviews, bibliometric analysis can present objective criteria to evaluate the developments in a research field. They can also serve as a useful tool to measure scholarship quality and productivity (Aparicio et al. 2019, Cobo et al. 2015). In addition, the systematization and replication processes offered by this method can enhance understanding of the knowledge dissemination in a field and can point out research gaps and directions to advance the discipline. Zupic and Čater (2015) further claim that bibliometrics provides "a systematic, transparent and reproducible review process", which helps describe, evaluate and monitor published research. Therefore, bibliometric analyses can bring new insights into the entrepreneurial finance field as a complement to previous research.

Therefore, given the complexity and dynamics in the entrepreneurial finance field, we aim to provide an overall picture of the discipline by using bibliometrics to fulfill the following research objectives:

1. To examine the most productive and influential journals in entrepreneurial finance discipline.

2. To explore the collaboration patterns across levels (individual, institution, and countrylevel) in entrepreneurial finance discipline.

3. To present the most influential articles and main research domains in entrepreneurial finance discipline.

To fulfill these objectives, we employ an analysis of 6,903 articles retrieved from the WoS database. The study finds the exponential increase in the number of publications as well as an increasing trend of collaboration within the field between 1970 and 2019. The period from 2011 to 2019 witnesses a magnificent rise in the number of publications, authors, and publishing journals in this discipline. Additionally, the Journal of Business Venturing is a long-standing prestigious journal, while Sustainability is a quickly rising player in the last few years.

The results, to some extent, also signal a Western ideological homogeneity in entrepreneurial finance research. The two characteristics that likely form this ideological homogeneity environment in the discipline are ideological hegemony and homogenous social circle of top researchers. In particular, among the ten most relevant authors (using full counting) and ten most influential authors, there is no author affiliated with countries outside Europe and North America. Also, a close-knit scientific community of top institutions in Europe and North America could be observed when plotting the collaboration network of 50 most representative institutions. 
Furthermore, "alliances" of top Western authors, or "supreme groups" can be found when investigating the collaboration network among 60 most representative authors. On the other hand, although China had an impressive performance in terms of publications, its impact is still limited compared to Western countries. This Western ideological homogeneity may create some disadvantages for the intellectual inquiry and debate of the discipline, as the minority may be less willing to share their opinions or change their viewpoints to be consistent with the majority. Therefore, a more ideologically diverse environment will significantly benefit economies worldwide. In such an environment, the most appropriate ideology can be applied to a particular nation to promote economic development as well as to receive less resistance from the institutional and socio-cultural filter process of that country.

We also identify seven main research domains employing authors' keyword co-occurrence analysis, including "venture capital", "crowdfunding", "SMEs finance", "social entrepreneurship finance", "financial risk", "microfinance", and "human-social-financial capital". Among these, further research is much needed in the "venture capital" and "crowdfunding" domains, as the two most important financing methods of entrepreneurs. The current body of literature indicates that these have a substantive connection with other themes within the field, but the internal links have not been fully built up.

The remainder of this paper proceeds as follows. Section 2 presents the Materials and Methods employed. Section 3 presents the main results. Section 4 provides a discussion of the results and a conclusion.

\section{Materials and Methods}

\subsection{Bibliometric analysis}

The method employed in the current study is bibliometrics, which uses statistical tools to analyze scientific publications (e.g., books, research articles, and so on) from an appropriate scientific database to evaluate research output, collaboration pattern, and citation impact metrics (Haustein and Larivière 2015). For detecting the most influential papers in the field, we employ the local citation score, while the global citation score is used to estimate the impact of sources and authors. Also, we utilize the co-authorship analysis and author's keyword co-occurrence analysis to study the social structure in three levels (individual, institution, and country) and the conceptual structure of the entrepreneurial finance research field, respectively.

\subsubsection{Local citation score}

For detecting the most influential articles in the entrepreneurial finance field, we employ local citation score (LCS), but for most influential sources and authors, we utilize a global citation score (GCS). GCS, also called normal citation score, is the most commonly used bibliometric indicator for measuring the impact of a scientific paper by counting the number of papers that have cited it. However, the GCS is not efficient to measure the impact of a paper in a single discipline, because it might encompass the number of times that the paper has been cited by works from other disciplines, especially in an increasingly interdisciplinary era (Cuccurullo et al. 2016, Gewin 2014). Thus, the LCS - calculated by counting how many times the paper has been cited by other papers in the extracted collection, can be a better indicator to measure the influence of a paper within the entrepreneurial finance. The LCS indicator was created by Garfield et al. (1964) - some 
of the founders of bibliometrics, for studying the history of science. Due to the lack of computational power at that time, the indicator had not been widely used until the later development of a software called HistCite (Garfield et al. 2002). Even though the LCS is initially developed to identify the most prominent scientific events/publications for historiographic analysis, its function can be properly used to search for most influential papers, authors, and sources in a single discipline (Garfield et al. 2006).

Nevertheless, when searching for most influential authors and sources, the algorithm also counts all the publications written by the author or published by the source without considering whether those publications are in the collection or not, so we use GCS for measuring the impact of sources and authors instead. Moreover, by utilizing the GCS for detecting the most influential authors and sources, the h-index of each author and source can be estimated.

\subsubsection{Social and conceptual structure networks}

Science mapping is one of the major components of bibliometrics, besides scientific output and impact evaluation. For studying the collaboration patterns across levels (individual, institution, and country), we employ the science mapping workflow suggested by Cobo et al. (2011b) and Aria and Cuccurullo (2017): study design, data retrieval, data analysis (descriptive analysis, network matrix creation, and normalization), data visualization (mapping), and interpretation. The current study aims to explore two out of three structures of knowledge (K-structures): conceptual structure (studied by co-word analysis), and social structure (studied by co-author analysis). Next, we explain how the data analysis is conducted.

Descriptive analysis. Before constructing the network matrixes, we provide some descriptive information regarding the top ten most productive authors (institutions and countries), as those authors (institutions and countries) will be included in the network analysis. Here, top authors are ranked using both full and fractional counting due to the advantages and disadvantages of both counting methods on measuring authors' productivity (Gauffriau 2017). Top institutions and countries are examined using article count (full counting at the institution- and country- levels). This counting method is used by Nature Index (2019) to track research output of institutions and countries: "A country/region or an institution is given an article count of 1 for each article that has at least one author from that country/region or institution". We choose article count because it is more intuitive than fractional count and compatible with the full counting measure in the collaboration analysis. Regarding the descriptive analysis of authors' keywords employed in word co-occurrence analysis, we exclude it from the paper since it only produces trivial information.

Network matrix creation and normalization. For establishing the collaboration and word network matrixes, the full counting approach is preferable for several reasons. The idea of fractional counting is to mitigate the influence of documents with many authors for field normalization (Perianes-Rodriguez et al. 2016), so fractional counting should be used in a bibliometric study examining multiple fields concurrently. Compared to the full counting method, fractional counting "is the logical procedure," but "it violates the intuitive judgment of many scientists" (Gauffriau 2017, Lindsey 1980), especially in collaboration and word co-occurrence analyses. Even the CWTS Leiden Ranking, in which fractional counting is used to calculate scientific impact indicators, stated: "Collaboration, open access, and gender indicators are always calculated using the full counting method” (The CWTS Leiden Ranking 2019). 
The collaboration analysis and co-word analysis are two of the most common bibliometric techniques. The collaboration analysis employs author, country, and institution from affiliation as units of analysis to present the co-occurrence of authors, institutions, and countries in a network. In the network, nodes (representing author, institution, or country) are connected by links to form the co-authorships. The following general formula is used to obtain the collaboration network (Aria and Cuccurullo 2017):

$B_{\text {coll }}=A_{\text {coll }} \times A_{\text {coll }}^{\prime}$

$\mathrm{A}_{\text {coll }}$ is a rectangular matrix Document $\square$ Attribute (author, institution, or country), in which each row is a document $(i)$, and each column is an attribute of the collection $(j)$ (author, institution, or country). If a document holds an attribute, the generic element $a_{i j}$ equals to " 1 ", otherwise it is " 0 ". The sum of $j$-th column is the number of papers produced by the attribute, while the sum of $i$-th row is the number of attributes collaborating to produce the $i$-th document. Matrix $\mathrm{A}_{\text {coll }}$ and its transpose $\mathrm{A}^{\prime}$ coll are later used to create a non-negative and symmetrical matrix $\mathrm{B}_{\text {coll }}\left(\mathrm{B}_{\text {coll }}=\right.$ $\left.\mathrm{B}^{\prime}{ }_{\text {coll }}\right)$, in which columns and rows of the matrix are comparably made from attributes of the collection. As a result, element $b_{\mathrm{ij}}$ annotates the number of existent collaborations between attribute $i$ and $j$, while the diagonal element $\mathrm{b}_{\mathrm{ii}}$ is how many collaborations obtained by $i$-th attribute (author, institution, or country).

As for the co-word analysis, the resources for analysis can be keywords or terms extracted from title, abstract, keyword Plus, author's keyword, or even the document's body. The keyword cooccurrence network is also obtained through an almost similar formula with collaboration analysis:

$B_{\text {cow }}=A_{\text {cow }} \times A_{\text {cow }}^{\prime}$

$A_{\text {cow }}$ is a rectangular matrix Document $\mathrm{x}$ Word, in which each row represents a document, and each column is attributable to a word or term. The construct of matrix $A_{\text {cow }}$ is similar to that of matrix $A_{\text {coll }}$. In matrix $B_{\text {cow }}$, element $b_{i j}$ indicates the number of existent co-occurrences between words $i$ and $j$, while the diagonal element $b_{i i}$ addresses how many times the word $i$ appears in the collection, or how many documents contain the word $i$.

Normalization can be conducted after the network has been built to control the variation of the cooccurrence data. Four main similarity measures are the association strength (or proximity index), the Inclusion Index (or Simpson's coefficient), the Jaccard's coefficient, and the Salton's cosine. Van Eck and Waltman (2009) suggest that the co-occurrence data are best normalized employing a probabilistic measure, which is the association strength. Therefore, association normalization is used in our co-occurrence analysis. To calculate the association strength, the following formula is used given the established matrix $B_{\text {cow }}$ :

$S_{A_{-} i j}=\frac{b_{i j}}{b_{i i} \times b_{j j}}$

$S_{A_{-} i j}$ is the association strength calculated by the ratio between the observed and expected strength under the assumption of probabilistic independence. 
Thematic mapping, built upon the co-occurrence network and clusters, is another technique in the co-word analysis. The map is a two-dimensional diagram characterized by two parameters: "density" (x-axis) and "centrality" (y-axis), which helps categorize themes into four domains (Cobo et al. 2011a):

- The upper-right quadrant: themes in this area are called motor themes, which are both well developed and important for the structuring of a research field. Themes in this quadrant show strong centrality (high degree of external interaction) and high density (high internal strength of the network). The centrality and density can be measured by the formula proposed by Callon et al. (1991).

- The upper-left quadrant: themes in this area are internally well-developed, but lack external interaction with other themes, so they are very specialized and peripheral in character.

- The lower-right quadrant: themes in this area are important for a research field due to their high centrality, but not developed. The characteristics of these themes are transversal, general, and basic.

- The lower-left quadrant: The themes in this area are both undeveloped and marginal because of their low centrality and density. Themes in this quadrant can be emerging themes or vanishing themes.

In sum, the full counting method is used throughout the paper (fractional counting is used additionally only for measuring authors' productivity). We employ i) collaboration analysis for studying the social structure of authors, institutions, and countries and ii) co-word analysis (thematic mapping) for studying main themes in the entrepreneurial finance research field. For collaboration analysis, we do not use any normalization technique, but for co-occurrence analysis and thematic mapping, we choose association normalization.

\subsection{Search strategy}

To conduct a bibliometric analysis, selecting a proper database is very important. The current study examines the landscape of research regarding entrepreneurial finance with data retrieved from the Web of Science (WoS) database of Clarivate. WoS is one of the most reputable and long-standing databases in both Natural Sciences \& Engineering and Social Sciences \& Humanities. Because the database covers a significant range of high-quality journals published from 1900 to present, it has been used by governmental agencies and international organizations for assessing scientific performance and quality of authors and institutions (Clarivate Analytics 2020).

Entrepreneurial finance is a field encompassing the intersection of two major fields "entrepreneurship" and "finance". Studies in entrepreneurial finance do not simply examine how entrepreneurs make a financial decision or allocate financial resources (Paré et al. 2009), but they are relatively interdisciplinary linking fields, such as public policy, psychology, sociology, and geography, other than entrepreneurship and finance (Cumming and Johan 2017). Therefore, we define entrepreneurial finance as any studies that are related to financial issues among entrepreneurs and organizations with entrepreneurial orientation. It is notable that, here, we do not consider entrepreneurial finance to entirely cover the research in venture capital, because although venture capital is an important funding source for entrepreneurs, the venture capital research is not always about the relationship between entrepreneurship and venture capital. For example, studies 
on venture capital also encompass aspects not related to entrepreneurship, such as the performance of venture capitalists and the relationship between venture capitalists and other participants in the venture industry (e.g., private investors, investment bankers, IPO, public markets, etc.). Apparently, it is fuzzy to determine which paper related to venture capital should or should not be included in the entrepreneurial finance field, as subjective experience and background will affect the result among scholars. For that reason, employing search queries that generate results mentioning the keywords of both entrepreneurship and venture capital can be viewed as an objective approach, despite several limitations that we would explain in the Discussion.

Based on prior bibliometric studies about entrepreneurship (Aparicio et al. 2019, Vallaster et al. 2019) we utilize the keyword search with the following words: "entrepreneur*" (entrepreneur, entrepreneurs, entrepreneurial, and entrepreneurship), "startup*", "start-up*", "new enterprise*”, and "new firm*". For finance, we review studies of Padilla-Ospina et al. (2018), Xu et al. (2018), Zhang et al. (2019), and Cumming and Groh (2018), and determine to use the following search keywords: "financ*" (finance, financing, financial, financer, and financier), "debt*", "venture capital*" (venture capitalist and venture capitalists), "trade credit*", "crowdfund*" (crowdfunding, crowdfunded, crowdfunding, and Crowdfunder), "angel invest*", "private equit*" (private equity and private equities), and "IPO*".

The search was conducted on the 2nd March 2020 through the field tag "Topic". The search can be replicated using the following search query:

("entrepreneur*" OR "startup*" OR "start-up*" OR "new enterprise*" OR "new firm*")
AND
("financ*" OR "debt*" OR "venture capital*" OR "trade credit*" OR "crowdfund*" OR "angel
invest*" OR "private equit*" OR "IPO*")

When conducting the search on the WoS database, the following three inclusive criteria are adopted: (1) the publication is written in English, (2) the publication is a research article, and (3) the publication is published during the 1900-2020 period.

\subsection{Exclusive criteria}

After retrieving articles from the online database, we curate the data and exclude unqualified data. The criteria for excluding the retrieved items follow: (1) the publication is published in 2020, (2) the publication has no publication year, (3) the publication is a retracted article, book, book section, proceeding paper, or data paper, and (4) the publication is anonymous. We do not include any book, proceeding paper, and other types of publications except for research articles because either WoS or Scopus concentrate more on journals and less on other means of scientific knowledge dissemination (Mongeon and Paul-Hus 2016).

\subsection{Procedure}

The data are initially downloaded from the Web of Science (WoS) database based on the aforementioned keywords and inclusive criteria under the .txt format. The data consist of authors' names, authors' affiliations, titles, publication sources, abstracts, keywords, and cited references. The downloaded data are later curated and excluded unqualified publications in Excel after converting from txt files. The Bibliometrix R package is employed to analyze and extract specific 
data from the .txt format. Bibliometrix is an open-source tool designed for studying scientometrics and bibliometrics of data from SCOPUS, WoS, PubMed, and Cochrane databases (Aria and Cuccurullo 2017). In the current study, we employ the following data:

- Authors' information (co-authors, institutions, and countries)

- Articles' information (sources, number of citations, author's keywords, and references)

- Journal Impact Factor (JIF) in 2018

\section{Results}

\subsection{Scientific performance and most influential journals}

This section provides an overview of the research landscape on entrepreneurial finance from 1970 to 2019. We observe two major trends: the exponential growth of research output and the increasing collaboration pattern within the field. We also identify the most influential journals.

\subsubsection{Publication output}

From 1970 to 2019 , we record a total of 6,903 publications by 12,855 different authors in 1,891 journals. There is a significant growth in the number of publications, sources, and authors after every period. The increase in the number of documents, sources, and authors during the period 2011-2019 is impressive; solely the proportion of materials, sources, and authors during this period account for $75.22 \%, 86.15 \%$, and $81.86 \%$ of total numbers during $1970-2019$, respectively. The increasing number of authors per document over time and the decreasing share of single-authored papers hint at the rising collaboration trend among researchers in the discipline of entrepreneurial finance. The group size measured by the collaboration index also slightly decrease from 2.5 during 1970-1990 to 2.34 during 2011-2019, which hints at the fact that researchers in this field tend to collaborate in a smaller group.

Table 1. Scientific performance during four specific periods. This table provides general information about research output in four periods, including the number of documents, authors, sources, and single-authored works as well as the collaboration index. The number of authors in multi-authored articles and number of multi-authored articles are employed to calculate the collaboration index, which is used to measure the group size. We also calculate citations per document using a global citation score recorded from the publishing date to the extracted date. More details are discussed in sub-section 3.1.1. 


\begin{tabular}{ccccc}
\hline & $\mathbf{1 9 7 0 - 1 9 9 0}$ & $\mathbf{1 9 9 1 - 2 0 0 0}$ & $\mathbf{2 0 0 1} \mathbf{- 2 0 1 0}$ & $\mathbf{2 0 1 1} \mathbf{- 2 0 1 9}$ \\
\hline Documents & 23 & 448 & 1239 & 5193 \\
Sources & 19 & 200 & 474 & 1629 \\
Authors & 31 & 736 & 2203 & 10523 \\
Citations per document & 8.09 & 77.46 & 54.54 & 9.32 \\
Authors per document & 1.35 & 1.64 & 1.78 & 2.03 \\
Single-authored documents $(\%)$ & $16(69.57 \%)$ & 214 & 385 & 1151 \\
Collaboration Index & 2.5 & $(47.77 \%)$ & $(31.07 \%)$ & $(22.17 \%)$ \\
\end{tabular}

Citations per document $=$ Total citations (of documents published in specific period) until the extracted date/Total number of documents published in that period Collaboration Index $=$ Total Authors of Multi-Authored Articles/Total Multi-Authored Articles

\subsubsection{Annual publications}

Figure 1. The annual number of publications in entrepreneurial finance from 1970-2019. The bar chart illustrates the number of publications per annum. The two green dashed lines present the exponential and linear estimations of annual scientific growth in the field of entrepreneurial finance, with $\mathrm{x}=\mathrm{year}$, and $\mathrm{y}=$ number of publications per annum. More details are discussed in subsection 3.1.2.

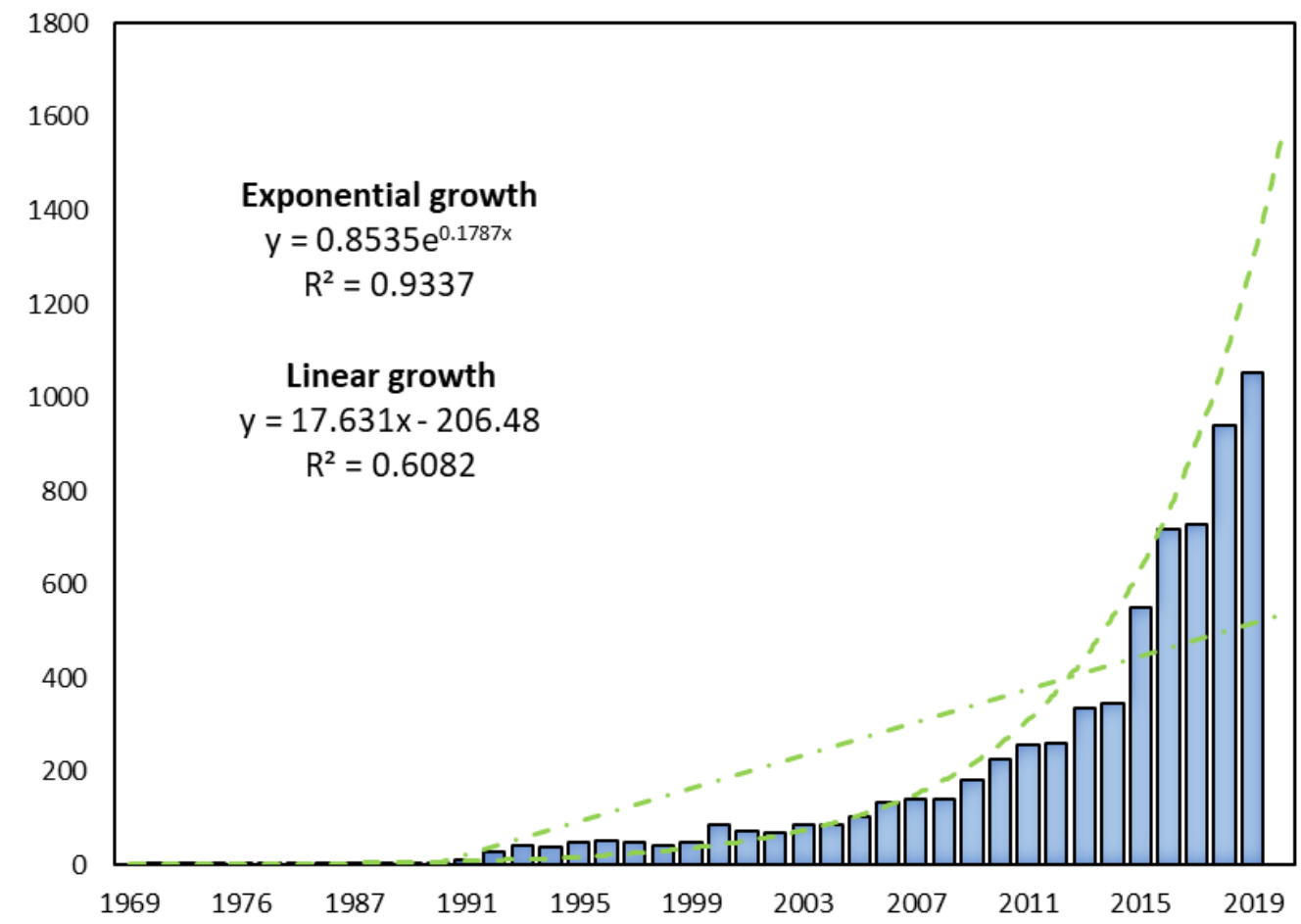


Entrepreneurial finance is a relatively young field of science and has been growing dramatically in the last 30 years. Figure 1 shows the annual number of publications related to the financing issues of entrepreneurs from 1970 to 2019 with exponential and linear estimations. Apparently, the exponential estimate $(\mathrm{R} 2=0.93)$ can explain the research output growth in this field better than the linear one $(\mathrm{R} 2=0.61)$. Overall, the annual growth rate of research articles is $19.54 \%$. In the first 20 years, the number of studies is almost unobservable, with only 1 or 2 studies recorded per year. Nonetheless, since the early 1990s, scientists have paid much more attention to this research field, which fuels the rapid increase in research output. Notably, the number of publications in 2015 almost doubled the number of publications in the previous year. This unexpected increase might be the consequence of the emergence of 'crowdfunding' as a new method of financing among entrepreneurs. The term 'crowdfunding' barely appears more frequently in 2010 (Cumming and Groh 2018), but it has now become one of the most attractive research topics within the discipline (Belleflamme et al. 2014, Mollick 2014).

\subsubsection{Most influential journals}

Among journals publishing articles related to entrepreneurial finance, the five most productive journals are Journal of Business Venturing, Small Business Economics, Entrepreneurship Theory and Practice, Journal of Small Business Management, and Sustainability, respectively.

The dominance of the Journal of Business Venturing and Small Business Economics in the number of articles can be seen in Table 2. The number of articles published by journals ranked 3rd to 10th are comparatively similar, but from the journal ranked 2 nd, the number increases by more than two-fold compared to the 3rd one. Journal of Business Venturing is the most productive and impactful within the discipline with 251 publications, h-index of 88, and 26,900 citations, which makes up $17.83 \%$ of the total number of citations. It also acquires JIF of 6.33, which is far higher than other journals (see Table 3).

Table 2. Top ten sources for scientific output in the entrepreneurial finance discipline. This table lists ten most productive journals in the field based on the full counting of the number of publications accumulated from 1970 to 2019. The JIF - journal impact factor, is drawn from the 2018 Journal Citation Report of Clarivate. Journals with JIF $=0$ or no JIF will be marked as N/A (not applicable). More details are discussed in sub-section 3.1.3.

\begin{tabular}{cccc}
\hline Rank & Sources & Number of articles & JIF \\
\hline 1 & Journal of Business Venturing & 251 & 6.33 \\
2 & Small Business Economics & 232 & 3.56 \\
3 & Entrepreneurship Theory and Practice & 93 & 6.19 \\
4 & Journal of Small Business Management & 89 & 3.12 \\
5 & Sustainability & 81 & 2.59 \\
6 & Journal of Business Research & 79 & 4.03 \\
7 & Research Policy & 68 & 5.43 \\
\hline
\end{tabular}




\begin{tabular}{cccc}
\hline 8 & Entrepreneurship and Regional Development & 64 & 2.93 \\
9 & Venture Capital & 61 & N/A \\
10 & International Entrepreneurship and Management Journal & 58 & 2.54 \\
\hline
\end{tabular}

The superior influence of the Journal of Business Venturing on the discipline results partly from its long-standing contribution since 1987 (see Figure 2). Only publishing a few papers each year before 2005, Small Business Economics started to expand its output ever since. During 2011-2019, the journal even surpassed the Journal of Business Venturing to be the most productive journal (see Table S1). The Journal of Small Business Management did not change their output much during 1994-2014 but has promptly increased their output in this field since 2015. The production of Entrepreneurship Theory and Practice has been growing slowly with new peaks over the years. Remarkably, the impressive emergence of Sustainability during the last four years hints at the undergoing concern of sustainability and interdisciplinarity in the field of Entrepreneurial Finance, such as (Fan and Zhang 2017, Giang et al. 2018, Martínez-Climent et al. 2019, Nigri and Del Baldo 2018, Scutariu et al. 2016, Usman et al. 2019).

Table 3. Top ten sources for scientific impact in the entrepreneurial finance discipline. This table lists ten most impactful journals in the field based on the full counting of global citation scores accumulated from 1970 to 2019. A journal's total citation share is calculated by dividing its citations with the total citations received by all journals (150,860 citations). The $\mathrm{h}$-index is the maximum value of $h$ such that the journal has published $h$ papers that have been cited at least $h$ times. The JIF - journal impact factor, is drawn from the 2018 Journal Citation Report of Clarivate. More details are discussed in sub-section 3.1.3.

\begin{tabular}{cccccc}
\hline \multirow{2}{*}{ Rank } & Sources & $\begin{array}{c}\text { Total } \\
\text { citation }\end{array}$ & $\begin{array}{c}\text { Total } \\
\text { Citation } \\
(\%)\end{array}$ & $\begin{array}{c}h^{-} \\
\text {index }\end{array}$ & JIF \\
\hline 1 & Journal of Business Venturing & 26,900 & $17.83 \%$ & 88 & 6.33 \\
2 & Small Business Economics & 7,050 & $4.67 \%$ & 44 & 3.56 \\
3 & Entrepreneurship Theory and Practice & 4,417 & $2.93 \%$ & 37 & 6.19 \\
4 & Strategic Management Journal & 4,342 & $2.88 \%$ & 28 & 5.57 \\
5 & Journal of Financial Economics & 4,124 & $2.73 \%$ & 30 & 4.69 \\
6 & Journal of Finance & 4,097 & $2.72 \%$ & 24 & 6.20 \\
7 & Research Policy & 3,957 & $2.62 \%$ & 30 & 5.43 \\
8 & Academy of Management Journal & 3,045 & $2.02 \%$ & 22 & 7.19 \\
\hline
\end{tabular}




\begin{tabular}{cccccc}
\hline 9 & $\begin{array}{c}\text { Entrepreneurship \& Regional } \\
\text { Development }\end{array}$ & 2,263 & $1.50 \%$ & 27 & 2.93 \\
10 & Review of Financial Studies & 2,226 & $1.48 \%$ & 19 & 4.98 \\
\hline
\end{tabular}

Table 3 lists journals with most scientific impact, each accumulated over 2000 citations, with JIF from 2.93 to 7.2. Despite being most productive, half of the journals in Table 2 do not appear in Table 3, namely the Journal of Small Business Management, Sustainability, Journal of Business Research, Venture Capital, International Entrepreneurship, and Management Journal. Journal of Business Venturing, Small Business Economics, Entrepreneurship Theory and Practice keep being in top 3. Although Small Business Economics has the second-highest total citation and h-index, its JIF is relatively lower than other journals. It is interesting that during 1970-2010, three prestigious journals for "finance" research (Journal of Finance, Review for Financial Studies, and Journal of Financial Economics) were among top ten most relevant journals about entrepreneurial finance research, but all disappeared in the top ten during 2011-2019 (see Table S2). Along with that, the appearance of journals in "business" and "management" fields in the top ten during 20112019 hints at the shift of research target of entrepreneurial finance studies.

Figure 2. The annual output of five journals with the highest number of publications in entrepreneurial finance discipline accumulated from 1970 to 2019. The line chart presents the growth dynamics of the five most productive journals ranked by full counting of their publications from 1970 to 2019. More details are discussed in sub-section 3.1.3

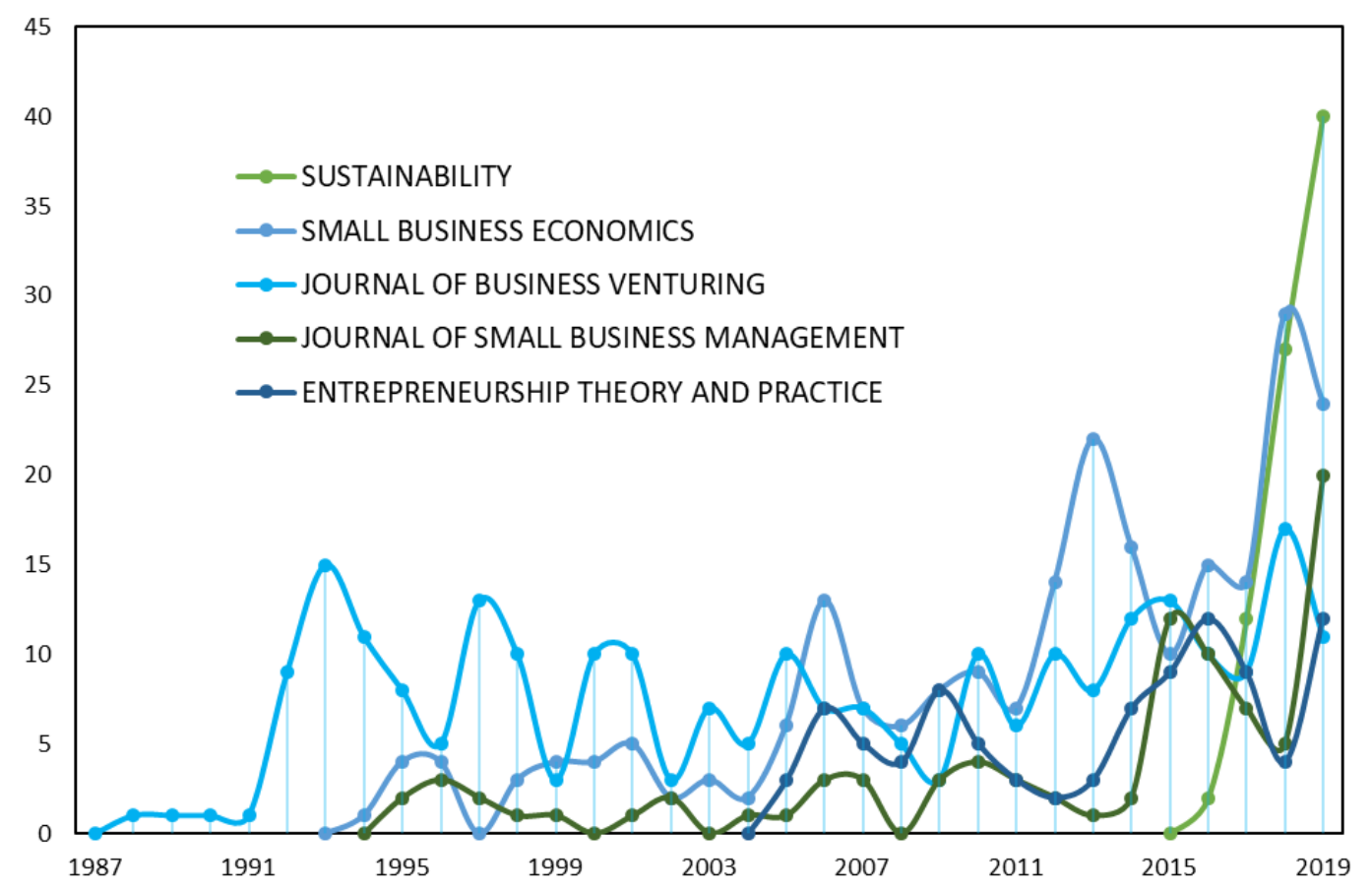




\subsection{Collaboration patterns}

In this section, we examine the collaboration patterns in studying entrepreneurial finance in three levels: author, institution, and country. The results from the national level to individual level signal the dominance of Western ideologies leading by authors and institutions from the United States of America (USA) in the discipline. In contrast, the lack of appearance from countries in continents other than Europe and North America is noticeable (Crew 2019). Unfortunately, those left-out countries include the Asia-Pacific area, which is currently the home of four out of the ten most productive countries in terms of research productivity, namely China, Japan, Korea, and Australia. Even though China exposes a sharp rise in scientific production that makes them ranked 4rd among the ten most productive countries, China's scientific impact is the lowest in terms of both citation per paper and average JIF.

\subsubsection{Most productive authors}

Among the top ten authors for scientific research based on full counting and fractional counting methods, the number of authors affiliated with institutes in Europe and North America is overwhelming (see Table 4). Wonglimpiyarat $\mathbf{J}$ is the only author whose affiliation was outside Europe and North America, but the total citations received by the researcher from Thailand is not in line with his/her production. It is also notable that European authors tend to collaborate to achieve higher scientific output than authors from other territories. In detail, 9 out of 11 most prolific authors (including Cumming D) based on full counting are affiliated with institutions in Europe, whereas with fractional counting, 5 out of 10 most prolific authors (including Cumming D) are from North America and Thailand.

Another observation is that Vismara S from the University of Bergamo, Italy, started his career in the topic of entrepreneurial finance in 2010, which is comparatively later than other researchers on the list. His success might be in touch with the recently rising topic of 'crowdfunding' (Rossi and Vismara 2018, Signori and Vismara 2018, Vismara 2016, 2019).

Table 4. Top ten most productive authors by full and fractional counting in entrepreneurial finance discipline. The table presents the ten most productive authors by both full and fractional counting. With full counting method, each author is given one credit per publication, i.e., three coauthors of an article are given one credit for each. The factional counting method considers the total credit of an article as one, so each co-author is assigned a fraction of one credit for their contribution, e.g., three co-authors of an article are given one-third credit for each. The first publication year shows the first year the author started to publish in this field, while the country and institution of an author is drawn from the author's last publication in 2019. More details are discussed in sub-section 3.2.1.

\begin{tabular}{cccccc}
\hline \multicolumn{5}{c}{ Full counting } \\
\hline $\begin{array}{c}\text { Ran } \\
\mathbf{k}\end{array}$ & Authors & $\begin{array}{c}\text { Count } \\
\mathbf{S}\end{array}$ & $\begin{array}{c}\text { First } \\
\text { publication } \\
\text { year }\end{array}$ & Institution & Country \\
\hline 1 & Wright M & 51 & 1992 & Ghent University & Belgium
\end{tabular}




\begin{tabular}{|c|c|c|c|c|c|}
\hline 2 & Cumming D & 48 & 2005 & $\begin{array}{c}\text { Florida Atlantic } \\
\text { University/University of } \\
\text { Birmingham }\end{array}$ & USA/UK \\
\hline 3 & $\begin{array}{c}\text { Schwienbacher } \\
\text { A }\end{array}$ & 24 & 2005 & SKEMA Business School & France \\
\hline 4 & Shepherd DA & 23 & 1999 & University of Notre Dame & USA \\
\hline 5 & Colombo MG & 21 & 2005 & $\begin{array}{c}\text { Polytechnic University of } \\
\text { Milan }\end{array}$ & Italy \\
\hline 6 & Zahra SA & 21 & 1991 & University of Minnesota & USA \\
\hline 7 & Vanacker T & 19 & 2006 & Ghent University & Belgium \\
\hline 8 & Grilli L & 18 & 2005 & $\begin{array}{l}\text { Polytechnic University of } \\
\text { Milan }\end{array}$ & Italy \\
\hline 9 & Vismara S & 18 & 2010 & University of Bergamo & Italy \\
\hline 10 & Clarysse B & 16 & 2005 & $\begin{array}{c}\text { Swiss Federal Institute of } \\
\text { Technology }\end{array}$ & $\begin{array}{c}\text { Switzerlan } \\
\mathrm{d}\end{array}$ \\
\hline 10 & Manigart S & 16 & 1994 & Ghent University & Belgium \\
\hline \multicolumn{6}{|c|}{ Fractional counting } \\
\hline $\begin{array}{c}\operatorname{Ran} \\
\mathbf{k}\end{array}$ & Authors-Frac & $\begin{array}{c}\text { Count } \\
\mathrm{s}\end{array}$ & $\begin{array}{c}\text { First } \\
\text { publication } \\
\text { year }\end{array}$ & Institution & Country \\
\hline 1 & Cumming D & 21.87 & 2005 & $\begin{array}{c}\text { Florida Atlantic } \\
\text { University/University of } \\
\text { Birmingham }\end{array}$ & USA/UK \\
\hline 2 & Wright M & 17.75 & 1992 & Ghent University & Belgium \\
\hline 3 & $\begin{array}{c}\text { Schwienbacher } \\
\text { A }\end{array}$ & 12.58 & 2005 & SKEMA Business School & France \\
\hline 4 & Zahra SA & 11.58 & 1991 & University of Minnesota & USA \\
\hline 5 & $\begin{array}{l}\text { Wonglimpiyarat } \\
\mathrm{J}\end{array}$ & 10 & 2006 & Thammasat University & Thailand \\
\hline 6 & Bates $\mathrm{T}$ & 9.67 & 1975 & Wayne State University & USA \\
\hline 7 & Shepherd DA & 9.50 & 1999 & University of Notre Dame & USA \\
\hline 8 & Grilli L & 8.75 & 2005 & $\begin{array}{c}\text { Polytechnic University of } \\
\text { Milan }\end{array}$ & Italy \\
\hline
\end{tabular}


Being the most productive author, Wright $\mathrm{M}$ is also the second most influential author. His works are referred to 3151 times, and his h-index is 27. In terms of scientific impact, Zahra SA is the most influential researcher in entrepreneurial finance even though he only publishes 21 papers. His classic works extend our understanding of corporate entrepreneurship and firm performance (Zahra 1991, 1993, Zahra and Covin 1995). It is notable that most of the authors (9/10) start in the 1990s and early 2000s, whereas Cumming D is the only author publishing most recently but ranked 5th among the top ten most influential authors with 2,290 citations.

All authors presented in Table 5 are from Western countries, and the impact of the USA in entrepreneurial finance is again affirmed as 8 of the most influential authors are affiliated with institutions in the USA. Cumming D and Hellmann T are two researchers from the UK, and Wright $\mathrm{M}$ is from Belgium.

Table 5. Top ten most influential authors by total citations in entrepreneurial finance discipline. The table presents the ten most impactful authors by full counting of global citation scores accumulated from their first to their last publications. The $h$-index is the maximum value of $h$ such that the journal has published $h$ papers that have been cited at least $h$ times. The first publication year shows the first year the author started to publish in this field, while the country and institution of an author was drawn from the author's last publication in 2019. More details are discussed in sub-section 3.2.1.

\begin{tabular}{|c|c|c|c|c|c|c|}
\hline Rank & Authors & $\begin{array}{l}\text { Total } \\
\text { citations }\end{array}$ & $\begin{array}{c}h \text { - } \\
\text { index }\end{array}$ & $\begin{array}{c}\text { First } \\
\text { publication } \\
\text { year }\end{array}$ & Institution & Country \\
\hline 1 & Zahra SA & 4358 & 19 & 1991 & $\begin{array}{l}\text { University of } \\
\text { Minnesota }\end{array}$ & USA \\
\hline 2 & Wright M & 3151 & 27 & 1992 & Ghent University & Belgium \\
\hline 3 & $\begin{array}{l}\text { Shepherd } \\
\text { DA }\end{array}$ & 2890 & 20 & 1999 & $\begin{array}{c}\text { University of Notre } \\
\text { Dame }\end{array}$ & USA \\
\hline 4 & Shane S & 2793 & 8 & 1994 & $\begin{array}{c}\text { Case Western Reserve } \\
\text { University }\end{array}$ & USA \\
\hline 5 & $\begin{array}{c}\text { Cumming } \\
\text { D }\end{array}$ & 2290 & 27 & 2005 & $\begin{array}{c}\text { Florida Atlantic } \\
\text { University/University } \\
\text { of Birmingham }\end{array}$ & USA/UK \\
\hline 6 & Stuart TE & 1808 & 3 & 1998 & $\begin{array}{l}\text { University of } \\
\text { California }\end{array}$ & USA \\
\hline
\end{tabular}




\begin{tabular}{ccccccc}
\hline 7 & $\begin{array}{c}\text { Hellmann } \\
\text { T }\end{array}$ & 1796 & 9 & 1998 & University of Oxford & UK \\
8 & $\begin{array}{c}\text { Carsrud } \\
\text { AL }\end{array}$ & 1607 & 3 & 2000 & Ryerson University & Canada \\
& $\begin{array}{c}\text { Krueger } \\
\text { NF }\end{array}$ & 1480 & 1 & 2000 & Boise State University & USA \\
9 & Reilly MD & 1480 & 1 & 2000 & $\begin{array}{c}\text { Montana State } \\
\text { University }\end{array}$ & USA \\
9 & Hoang H & 1203 & 1 & 1999 & $\begin{array}{c}\text { Case Western Reserve } \\
\text { University }\end{array}$ & USA \\
\hline
\end{tabular}

The author's collaboration network is also visualized. Initially, we visualize the network with 30 most representative authors, but the result is relatively dispersed. Thus, we increase the number to 60 most representative authors (see Figure 3). Astonishingly, most of the top ten authors for scientific impact and output collaborate heavily with each other and form three main groups, which we may call "supreme groups" in the discipline. Meanwhile, other researchers tend to work alone or in a small group with two to four people, which is confirmed by visualizing with 80 most representative authors. When plotting with a greater number of authors (100 and 120 most representative authors), larger groups of researchers start to emerge, but those groups are relatively peripheral compared to the "supreme groups". The result, therefore, can be considered unchanged. 


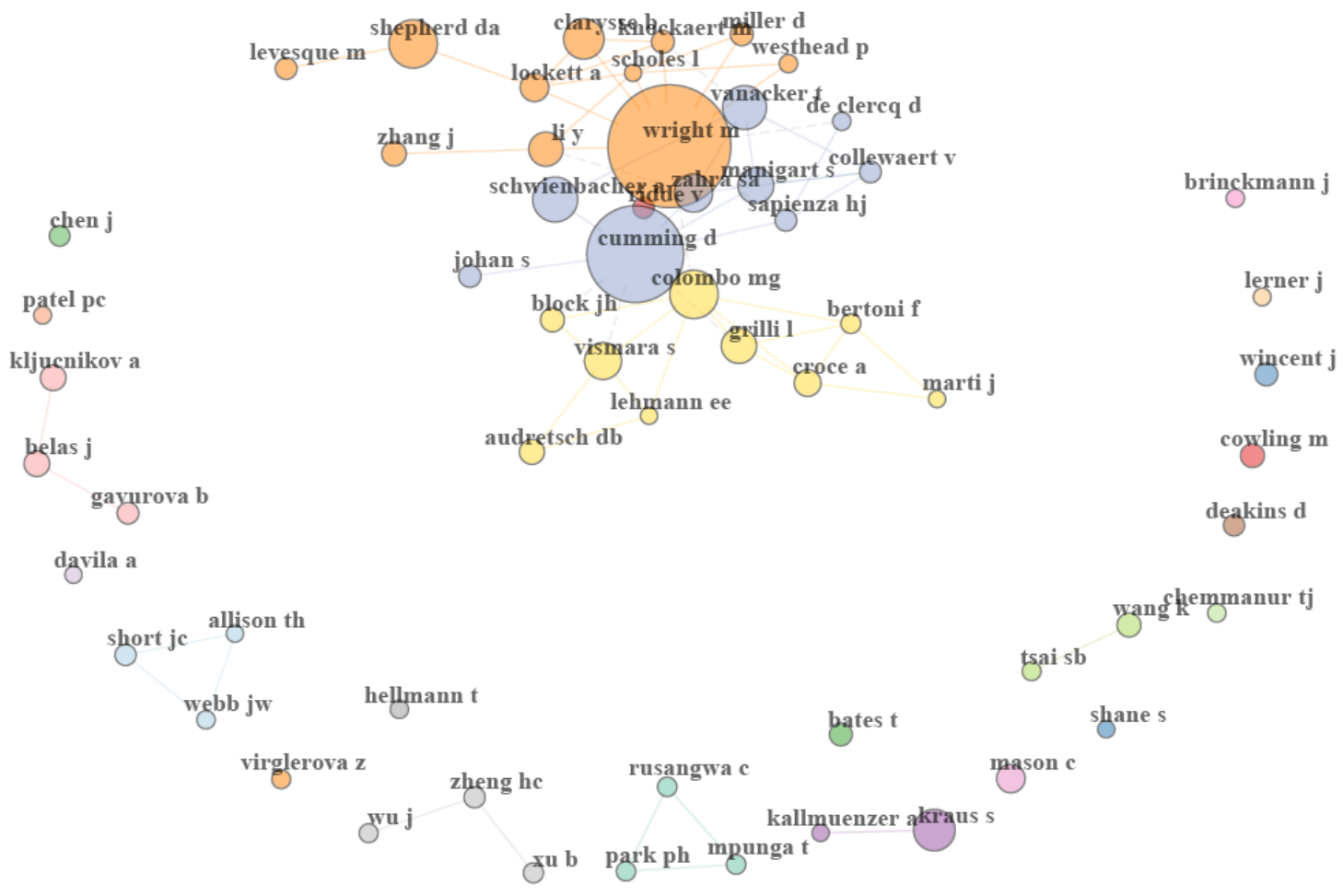

Figure 3. Collaboration network of 60 most representative authors in entrepreneurial finance discipline. The figure presents a collaboration network among 60 most productive authors. Each node (or vertex) on the undirected graph indicates a specific author with his/her name displayed in a label; the size of the node is proportional to the total node degree measuring how many links starts from or arrive in the given node. If there exists a co-authoring article between two or more authors, the nodes will be connected by links (or edges); otherwise, the node will obtain no connection link with other authors on the graph. A group of frequently collaborated authors will be clustered in the same color using the Louvain clustering algorithm, and the dotted line shows a cross-group collaboration between two authors in two different clusters. More details are discussed in subsection 3.2.1.

\subsubsection{Most productive institutions}

Table 6. Top ten institutions for scientific output in entrepreneurial finance discipline. Institutions with the highest number of publications by article counting during the 1970-2019 period are listed with their total citation and average JIF. The article count gives an institution one credit for each article that has at least one author from that institution. The average JIF is calculated by dividing the total JIF of all publications of the institution by the number of publications. The JIF is from the 2018 Journal Citation Report of Clarivate. Only articles published in journals with JIF $>0$ are considered for avoiding the bias that the JIF of journals not given the impact factor are also 0. More details are discussed in sub-section 3.2.2. 


\begin{tabular}{|c|c|c|c|c|c|}
\hline Ranking & Institution & Country & Articles & $\begin{array}{l}\text { Total } \\
\text { citation }\end{array}$ & $\begin{array}{c}\text { Average } \\
\text { JIF }\end{array}$ \\
\hline 1 & Harvard University & USA & 76 & 5250 & 4.61 \\
\hline 2 & Ghent University & Belgium & 75 & 2350 & 3.51 \\
\hline 3 & University of Nottingham & UK & 75 & 4294 & 3.27 \\
\hline 4 & Indiana University & USA & 73 & 2996 & 4.54 \\
\hline 5 & $\begin{array}{l}\text { University of North } \\
\text { Carolina }\end{array}$ & USA & 73 & 1922 & 3.85 \\
\hline 6 & Stanford University & USA & 68 & 6143 & 3.88 \\
\hline 7 & York University & Canada & 61 & 2355 & 3.74 \\
\hline 8 & University of Minnesota & USA & 60 & 3142 & 4.08 \\
\hline 9 & $\begin{array}{l}\text { Polytechnic University of } \\
\text { Milan }\end{array}$ & Italy & 58 & 1512 & 3.63 \\
\hline 10 & $\begin{array}{l}\text { Erasmus University } \\
\text { Rotterdam }\end{array}$ & Netherlands & 54 & 1773 & 3.80 \\
\hline
\end{tabular}

Table 6 shows the top ten institutions for scientific production on the topic of entrepreneurial finance; or, we may say ten powerhouses. The three most productive institutions are Harvard University in the USA, Ghent University in Belgium, and the University of Nottingham in the UK. Interestingly, all of the ten institutions are located in Western countries, among which six are in North America (the USA and Canada), while others are in Europe (United Kingdom, Belgium, Netherlands, and Italy). Making half of the list, the USA is home to most powerhouses of entrepreneurial finance research, including Harvard University, Indiana University, University of North Carolina, Stanford University, and the University of Minnesota. Ghent University in Belgium is the only institution having three researchers in the list of top ten authors for scientific production, who are Wright M, Vanacker T, and Manigart S.

We then visualize the collaboration network of 50 most representative institutions employing the Kamada-Kawai network layout (Figure 4). The network points out four main clusters: 1) green cluster - collaboration dominated by institutions within the USA, led by two powerhouses (Havard University and Stanford University), 2) red cluster - collaboration group dominated by institutions in the Europe and Canada, led by powerhouses outside of the USA (Ghent University, University of Nottingham, York University, Polytechnic University of Milan, and Erasmus University Rotterdam) 3) blue cluster - collaboration group dominated by institutions in the USA that have a close connection with the institution in Europe, led by the two powerhouses (Indiana University and North Carolina University), 4) orange cluster - collaboration group concurrently cooperating with institutions in the USA, Europe, and elsewhere, led by one powerhouse (University of Minnesota). Nevertheless, only two institutions from other regions besides Western countries 
appear in the network (Tsinghua University and the National University of Singapore), which indicates the weak knowledge exchange of institutions around the world apart from Western countries in the discourse of entrepreneurial finance. The visualization result from 80 and 100 most representative institutions reveals the merging of clusters 3 and 4 and the marginal appearance of several institutions from China and Hong Kong. Generally looking, there is not much difference in the bigger picture, which suggests the Western monocentric in the collaboration network

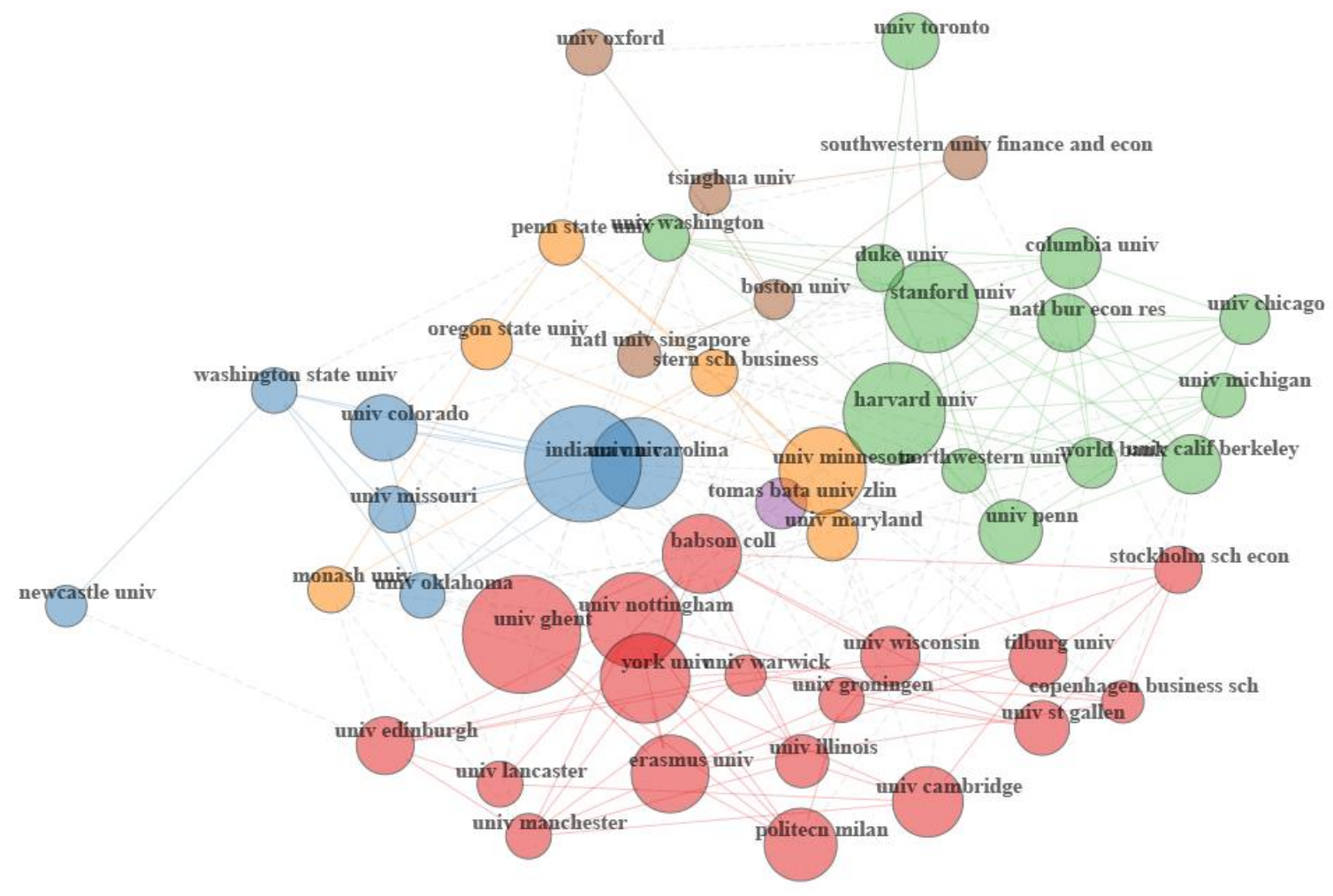

Figure 4. Collaboration network of 50 most representative institutions in entrepreneurial finance discipline. The figure presents a collaboration network among 50 most productive institutions. Each node (or vertex) on the undirected graph indicates a specific institution with its name displayed in a label; the size of the node is proportional to the total node degree measuring how many links starts from or arrive in the given node. If there exists a co-authoring article between two or more institutions, the nodes are connected by links (or edges); otherwise, the node obtains no connection link with other institutions on the graph. A group of frequently collaborated institutions is clustered in the same color using the Louvain clustering algorithm, and the dotted line shows a cross-group collaboration between two institutions in two different clusters. More details are discussed in subsection 3.2.2.

\subsubsection{Most productive countries}

Table 7. Top ten countries for scientific output in entrepreneurial finance discipline. Countries with the highest number of publications by article counting during the 1970-2019 period are listed with their total citation and average JIF. The article count gives a country one credit for each article that has at least one author from that country. The percentage is calculated by dividing the 
number of articles by the total number of articles in the collection (6,903 articles). The average JIF is calculated by dividing the total JIF of all publications of the country by the number of publications. The JIF is from the 2018 Journal Citation Report of Clarivate. Only articles published in journals with JIF $>0$ are considered for avoiding the bias that the JIF of journals not given the impact factor are also 0. More details are discussed in sub-section 3.2.3.

\begin{tabular}{ccccccc}
\hline Ranking & Country & Articles & $\begin{array}{c}\text { Percentag } \\
\mathbf{e}\end{array}$ & $\begin{array}{c}\text { Total } \\
\text { citation }\end{array}$ & $\begin{array}{c}\text { Average } \\
\text { citation }\end{array}$ & $\begin{array}{c}\text { Average } \\
\text { JIF }\end{array}$ \\
\hline 1 & USA & 2,268 & $32.86 \%$ & 77,933 & 34.36 & 3.48 \\
2 & UK & 973 & $14.10 \%$ & 22,247 & 22.86 & 3.07 \\
3 & Germany & 433 & $6.27 \%$ & 8,084 & 18.67 & 3.05 \\
4 & China & 426 & $6.17 \%$ & 5,694 & 13.37 & 2.59 \\
5 & Canada & 414 & $6.00 \%$ & 9,728 & 23.50 & 3.52 \\
6 & Italy & 316 & $4.58 \%$ & 4,655 & 14.73 & 3.08 \\
7 & France & 295 & $4.27 \%$ & 5,231 & 17.73 & 3.21 \\
8 & Spain & 277 & $4.01 \%$ & 4,675 & 16.88 & 2.81 \\
9 & Australia & 261 & $3.78 \%$ & 4,557 & 17.46 & 2.81 \\
10 & Netherlands & 244 & $3.54 \%$ & 5,159 & 21.14 & 3.26 \\
\hline
\end{tabular}

With 2,268 articles contributing $32.86 \%$ of the total publication, the USA is the most productive country. The scientific impact of the USA (77,933 citations, 34.36 citations per article, and 3.48 JIF on average) is also far ahead compared with others. For some countries, the number of articles does not reflect much of their impact. Netherlands authors have only 244 articles, but each of them is cited 21.14 times and published in relatively high impact factor journals on average. In a list dominated by developed Western countries, China is on the rise with 426 publications, but its impact is fairly low. The average citation and JIF of an article with China are 13.37 and 2.59, respectively, making them the least influential country in the top 10 . 


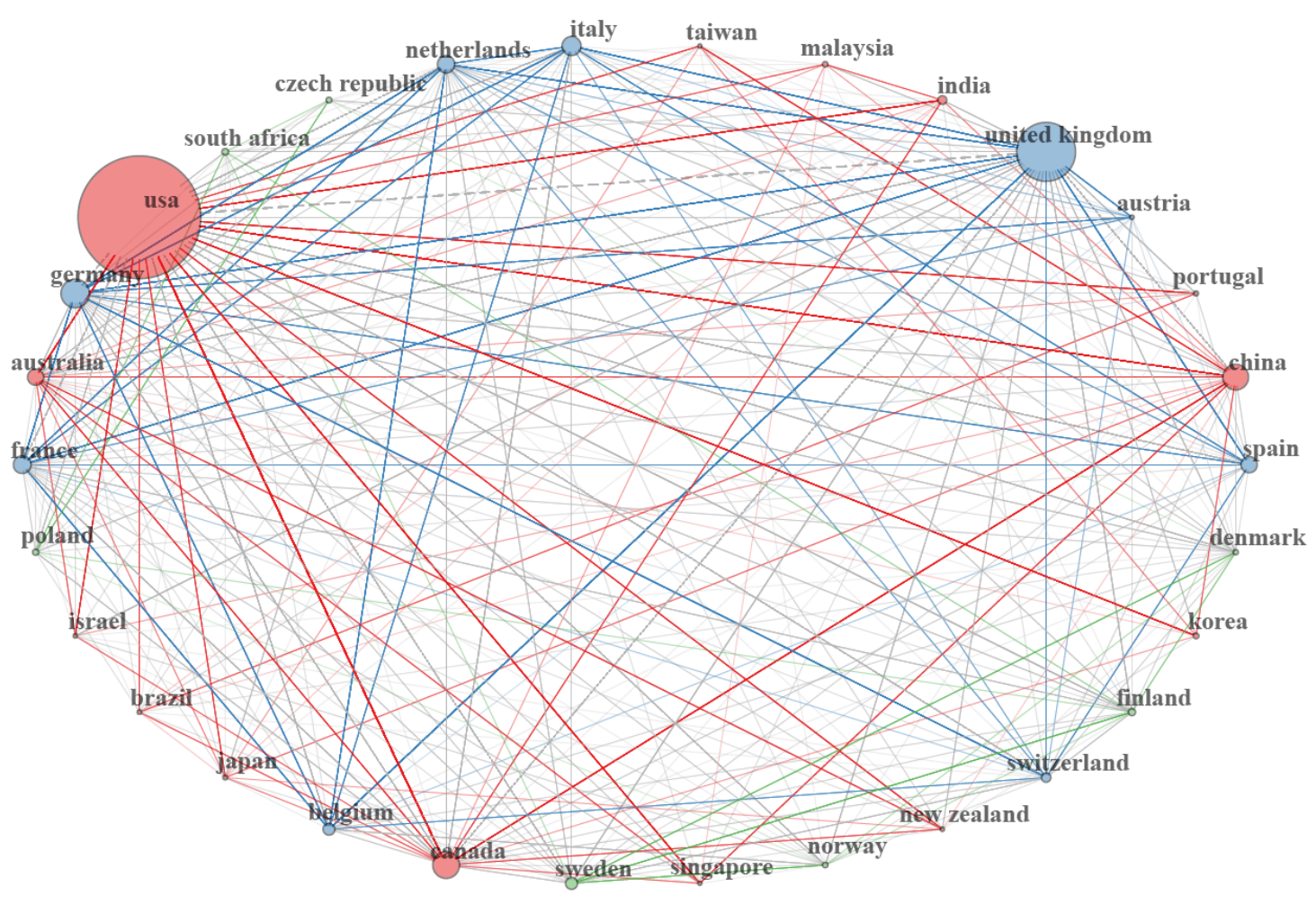

Figure 5. Collaboration network of 30 most representative countries in entrepreneurial finance discipline. The figure presents a collaboration network among the 30 most productive countries. Each node (or vertex) on the undirected graph indicates a specific country with its name displayed in a label; the size of the node is proportional to the total node degree measuring how many links starts from or arrive in the given node. If there exists a co-authoring article between two or more countries, the nodes are connected by links (or edges); otherwise, the node obtains no connection link with other countries on the graph. A group of frequently collaborated countries is clustered in the same color using the Louvain clustering algorithm. More details are discussed in subsection 3.2.3.

The collaboration network of 30 most representative countries presents three clusters of international collaboration among countries: i) North America and Asia, ii) Western Europe, including Italy, iii) South Africa, North Europe, and Central Europe (see Figure 5). The dominance sign of Western countries in the research topic of financial issues among entrepreneurs is relatively transparent that North American and European countries create three main collaboration networks and greatly contribute to them. The finding provides an additional piece of evidence on the influence of Western countries in the field of entrepreneurial finance.

\subsection{Most influential articles and main research domains}

\subsubsection{Most influential articles}

Table 8 lists the ten most locally cited articles studying financial issues among entrepreneurs. With three over ten articles highly cited within the discipline, the Journal of Business Venturing can be considered a top performer. The journal has both a large quantity and profound impact on the 
discourse of entrepreneurial finance. Novice researchers in this field are recommended to refer to this source for initiating a research project. Besides, as corresponding authors of 9 out of 10 articles are affiliated with institutions in the USA, the impact of the USA in this academic discussion is undeniable.

Table 8. Top ten articles for local citation in entrepreneurial finance discipline. Papers with the highest number of local citations are presented in the table. Local citation score measures how many times an article is cited by other articles in the same extracted collection. Other information about the articles (sources, year of publication, and the country of the corresponding author) is also included. More details are discussed in subsection 3.3.1.

\begin{tabular}{|c|c|c|c|c|c|c|}
\hline Rank & Title & Authors & Journal & Year & $\begin{array}{c}\text { Local } \\
\text { citations }\end{array}$ & $\begin{array}{c}\text { Corresponding } \\
\text { author's country }\end{array}$ \\
\hline 1 & $\begin{array}{l}\text { Venture Capital and } \\
\text { the Professionalization } \\
\text { of Start-Up Firms: } \\
\text { Empirical Evidence }\end{array}$ & $\begin{array}{l}\text { Hellmann T \& } \\
\text { Puri M }\end{array}$ & $\begin{array}{l}\text { The Journal of } \\
\text { Finance }\end{array}$ & 2002 & 276 & USA \\
\hline 2 & $\begin{array}{c}\text { Network Ties, } \\
\text { Reputation, and the } \\
\text { Financing of New } \\
\text { Ventures }\end{array}$ & $\begin{array}{c}\text { Shane S \& } \\
\text { Cable D }\end{array}$ & $\begin{array}{l}\text { Management } \\
\text { Science }\end{array}$ & 2002 & 241 & USA \\
\hline 3 & $\begin{array}{l}\text { The dynamics of } \\
\text { crowdfunding: An } \\
\text { exploratory study }\end{array}$ & Mollick E & $\begin{array}{l}\text { Journal of } \\
\text { Business } \\
\text { Venturing }\end{array}$ & 2014 & 240 & USA \\
\hline 4 & $\begin{array}{c}\text { Financial Contracting } \\
\text { Theory Meets the Real } \\
\text { World: An Empirical } \\
\text { Analysis of Venture } \\
\text { Capital Contracts }\end{array}$ & $\begin{array}{c}\text { Kaplan SN \& } \\
\text { Stromberg P }\end{array}$ & $\begin{array}{l}\text { Review of } \\
\text { Economic } \\
\text { Studies }\end{array}$ & 2003 & 221 & USA \\
\hline 5 & $\begin{array}{l}\text { Interorganizational } \\
\text { Endorsements and the } \\
\text { Performance of } \\
\text { Entrepreneurial } \\
\text { Ventures }\end{array}$ & $\begin{array}{l}\text { Stuart TA, } \\
\text { Hoang H \& } \\
\text { Hybels RC }\end{array}$ & $\begin{array}{c}\text { Administrative } \\
\text { Science } \\
\text { Quarterly }\end{array}$ & 1999 & 204 & USA \\
\hline 6 & $\begin{array}{c}\text { What Do } \\
\text { Entrepreneurs Pay for } \\
\text { Venture Capital } \\
\text { Affiliation? }\end{array}$ & Hsu DH & $\begin{array}{l}\text { The Journal of } \\
\text { Finance }\end{array}$ & 2004 & 194 & USA \\
\hline 7 & $\begin{array}{l}\text { Initial human and } \\
\text { financial capital as } \\
\text { predictors of new } \\
\text { venture performance }\end{array}$ & $\begin{array}{c}\text { Cooper AC, } \\
\text { Gimeno-Gascon } \\
\text { FJ \& Woo CY }\end{array}$ & $\begin{array}{c}\text { Journal of } \\
\text { Business } \\
\text { Venturing }\end{array}$ & 1994 & 180 & USA \\
\hline 8 & $\begin{array}{l}\text { The Venture Capital } \\
\text { Revolution }\end{array}$ & $\begin{array}{c}\text { Gompers P \& } \\
\text { Lerner J }\end{array}$ & $\begin{array}{c}\text { Journal of } \\
\text { Economic } \\
\text { Perspectives }\end{array}$ & 2001 & 174 & USA \\
\hline
\end{tabular}




\begin{tabular}{|c|c|c|c|c|c|c|}
\hline 9 & $\begin{array}{c}\text { The Interaction } \\
\text { between Product } \\
\text { Market and Financing } \\
\text { Strategy: The Role of } \\
\text { Venture Capital }\end{array}$ & $\begin{array}{c}\text { Hellman T \& } \\
\text { Puri M }\end{array}$ & $\begin{array}{c}\text { The Review of } \\
\text { Financial } \\
\text { Studies }\end{array}$ & 2000 & 160 & USA \\
\hline 10 & $\begin{array}{c}\text { Crowdfunding: } \\
\text { Tapping the right } \\
\text { crowd }\end{array}$ & $\begin{array}{c}\text { Belleflamme P, } \\
\text { Lambert T \& } \\
\text { Schwienbacher } \\
\text { A }\end{array}$ & $\begin{array}{c}\text { Journal of } \\
\text { Business } \\
\text { Venturing }\end{array}$ & 2014 & 159 & Germany and France \\
\hline
\end{tabular}

Hellmann T \& Puri M have two out of ten most impactful papers, both of which explore the role of venture capital. In the first paper, they examine the impact of venture capital on firms' professionalization (e.g., human resources policies, CEO replacement) (Hellmann and Puri 2002). Using data from Silicon Valley high-tech startups, their second paper, which is the 9th most highlycited one, focuses on how venture capital influences product marketing strategies of innovative firms (Hellmann and Puri 2000). The result suggests the significant relationship between venture capital and firms' product market dimensions.

Shane and Cable (2002) examine the entrepreneurial finance from the aspect of social capital. They find that social capital is a crucial determinant of venture's financing decisions by facilitating entrepreneurs and seed-stage investors to overcome information asymmetry problems.

"Financial Contracting Theory Meets the Real World: An Empirical Analysis of Venture Capital Contracts" written by Kaplan and Strömberg (2003), presents an empirical analysis of venture capital contracts of 200 investments in 118 portfolio firms among 14 venture companies. The result is compared with five financial contracting theories: the principal-agent problem, control theories, stealing theories, the inalienability of human capital theories, the venture capital-specific theories, and screening models. From that result, they draw out the level of consistency between theories and empirical findings, as well as show the incompleteness of these theories. This is a useful reference for researchers to inquire about financial contract theories.

The empirical research by Stuart et al. (1999) on venture-capital-backed biotechnology firms suggests the importance of inter-organizational networks to the survival and growth of young firms. They find that high-quality affiliations would positively enhance their image to third parties. Furthermore, being backed up by prominent strategic alliance partners and investors would also shorten the time to go to IPO and increase firm valuation at IPO. Another research by Cooper et al. (1994) investigates the survival rate and growth of new ventures from the aspect of financial capital, after employing data of 1053 new firms across all sectors and geographical regions.

Hsu (2004) explains how venture capitalists' reputation positively influenced the possibility that entrepreneurs would accept their offer. To be affiliated with reputable capitalists, founders are also willing to turn down offers with a higher valuation. Gompers and Lerner (2001) capture the history and revolution of venture capital. They gather empirical studies on venture capital, then note what remains unknown about the subject at that time. 
Most of the articles on the list are published before 2005. The other two articles about crowdfunding published in the Journal of Business Venturing are quite young but have already created a significant impact on the discipline. The finding highlights the tremendous interest of entrepreneurial finance researchers in this new Internet-based financing method.

In particular, the article written by Mollick (2014) investigates factors that influenced the success and failure of crowdfunding ventures. The author finds the association between personal network, underlying project quality, geography and fundraising success, and the link between the level/ amount of funds received and the degree of delay to fulfill founders' obligation (Mollick 2014). Another paper related to crowdfunding in the list is a comparative study between two forms of crowdfunding: pre-ordering and profit-sharing. The article implies that profit-sharing is the optimal alternative for entrepreneurs with enormous capital demand, and establishing a community assisting the entrepreneurs was vital for a feasible funding mechanism (Belleflamme et al. 2014).

\subsubsection{Main research domains}

To implement keyword co-occurrence analysis, we use thematic mapping instead of network visualization to examine the current development situation of each area. We employ 500 most representative words in the Author Keyword field rather than the Keyword Plus field because Author Keyword terms are as useful as Keyword Plus in exploring the knowledge structure of scientific fields but also provide a more comprehensive representation of the article's content (Zhang et al. 2016). Each detected domain is presented by a bubble on a bi-dimensional map. The terms/words in the bubble are terms/words with the highest number of occurrences within a domain. The bubble size is proportional to the word occurrences of the domain, and the bubble position on the map is given based on Callon's centrality and density.

Here, we present seven primary research domains with their current development situations (see Figure 6). The most extensive research domain (blue) is associated with the venture capital financing of entrepreneurs, so the domain is entitled "venture capital". This research domain has an extensive connection with other research domains, but low connection within the domain, which makes it relatively transversal. Researches in this domain usually concern the relationship between venture capital and innovation ability of new firms (Gu and Qian 2019, Santos and Qin 2019), the role of venture capital financing in China (Cheng et al. 2019), and gender issues in obtaining venture capital (Guzman and Kacperczyk 2019).

The second most substantial research domain is "crowdfunding" (orange). This domain is located on the x-axis, which indicates the growing internal links and considerable connection with other research domains. This domain focuses particularly on the crowdfunding topic; some exemplary studies are Cumming et al. (2019b), Foster (2019), Hervé et al. (2019), Vismara (2019), and Miller et al. (2019).

The third domain is related to the activities and financial performance of small-medium enterprises, so we called it "SMEs finance"(green) - the motor theme of the entrepreneurial finance field. The domain is not only well developed but also greatly interacted with other domains. Gomezel and Rangus (2018), Adomako (2018), Donkor et al. (2018), and Farrington et al. (2018) are some of the exemplary researches. Also, the SMEs' financial performance and internationalization are often concurrently examined (Gonzalez-Perez et al. 2018, Jin et al. 2018). 
The fourth domain (gray), entitled "social entrepreneurship finance", apparently examines how social entrepreneurs finance their businesses. Social entrepreneurship is businesses aiming to create social value through recognizing opportunities, employing innovation, tolerating risk, and declining to accept insufficient resources (Peredo and McLean 2006). The financing issues of social entrepreneurs in India attract substantial interest from researchers (Satar and John 2016, Tasavori et al. 2016, Verma 2017). Moreover, the financing issues of social entrepreneurship are frequently studied with sustainability issues (Gray et al. 2018, Laurell et al. 2019), which might require the expansion of external links (or centrality) due to the interdisciplinary nature of sustainability.

The fifth domain - "financial risk" (purple), is relatively specific to the financial risks of entrepreneurs. The knowledge within the domain is relatively developed, even though the number of publications in this issue is limited and not often connected to the mainstream research of entrepreneurial finance. Studies in this domain usually pay attention to financial frictions, financial distress, and risk of bankruptcy (Allub and Erosa Etchebehere 2014, Megginson et al. 2019, Stef and Jabeur 2018).

The last two domains have comparatively similar size, and all lie in the lower-left quadrant; they are either vanishing or developing. The red domain is associated with "microfinance", whereas the pink domain is related to "human-, social- and financial capital". For the "microfinance for entrepreneurs" domain, the most frequently studied topics are microfinancing for female entrepreneurs and poverty alleviation in developing countries (Alawattage et al. 2019, Hussain et al. 2019, Price 2019). Meanwhile, studies in the "social capital and financing" domain often use human-, social-, financial-capital lens concurrently to examine either the performance or the gain of entrepreneurs (Boudreaux and Nikolaev 2019, Macht and Chapman 2019). Notably, another main research topic is about the effect of social capital and social network on entrepreneurial finance (Ha and Frömmel 2019, Madrazo-Lemarroy et al. 2019). This approach is often employed to study how academic entrepreneurs finance for university spin-offs (Huynh 2016, 2019). 


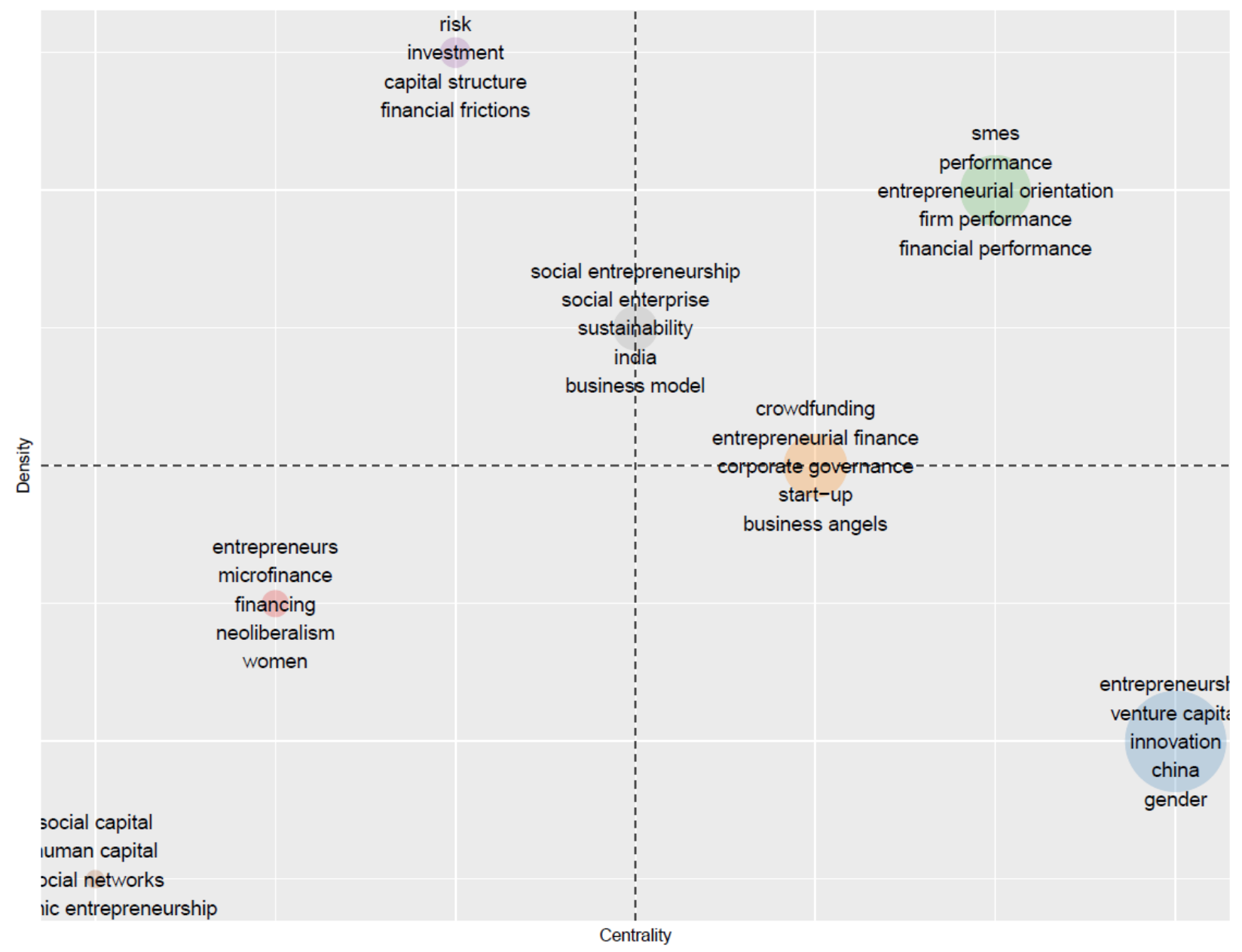

Figure 6. Thematic mapping of 500 most representative authors' keywords in entrepreneurial finance discipline. Thematic mapping is built based on the co-occurrence of authors' keywords for presenting seven major research domains in entrepreneurial finance: "venture capital", "crowdfunding", "SMEs finance", "social entrepreneurship finance", "financial risk", "microfinance", and "human-social-financial capital". Each bubble, representing a particular research domain, consists of the most frequently used keywords within that domain. The bubble size reflects the word occurrence of the domain. The thematic map consists of 4 quadrants, and the placement of the bubble is based on its centrality (how well it connects with other domains) and density (how well it is developed). To be more specific, domains in the upper-right quadrant have a high degree of centrality and density, indicating they are well-developed and important to the field. Domains in the upper-left quadrant are very niche but well developed. Domains in the lowerleft quadrant are neither developed nor important, so they are considered as emerging or disappearing domains. Themes in the lower-right quadrant are not internally well-developed but relatively transversal. More details are discussed in subsection 3.3.2.

\section{Discussion and conclusion}

Entrepreneurial finance is a young blooming research discipline in which there is still muchuntapped area. To examine the scientific landscape and primary research domains of entrepreneurial finance, this study employs a bibliometric analysis of 6,903 articles retrieved from 
the WoS database. The study finds the exponential growth in publication number and an increasing degree of collaboration within the field during the period 1970 - 2019. Especially between 2011 and 2019, the discipline witnesses a magnificent rise in the number of publications, authors, and publishing journals. Moreover, while the Journal of Business Venturing is a long-standing prestigious journal, Sustainability is a rapidly rising "unicorn" in the last decade that reveals the sustainability and interdisciplinary perspective in entrepreneurial finance.

There exist some signs of Western ideological homogeneity in entrepreneurial finance research. Ideological homogeneity has been researched extensively, especially in political science. The term often refers to the lack of opinion diversity, as a majority hold similar opinion. Regarding the disadvantage of this phenomenon, under the influence of ideological homogeneity, the minority might be influenced to adjust their opinions to be in line with the majority, thus narrowing the realm of intellectual inquiry and debate (Atkeson and Taylor 2019, Wojcieszak 2010). The dominance of ideology may also result in the rejection of papers on unpopular subjects or with a contradictory point of view. As a result, scientists with less dominant views may find homogenous environments hostile; thus, they are less willing to share their opinions (Campbell 2019).

Based on the work of Nescolarde-Selva et al. (2017) and Atkeson and Taylor (2019), we find two characteristics that likely form an ideological homogeneity environment in entrepreneurial finance research: ideological hegemony and homogenous social circle of top researchers. First, the dominance of Western ideology, led by American authors and institutions, is observable. Our findings indicate that out of the ten most relevant authors (using full counting) and ten most influential authors, there is no author affiliated with countries outside Europe and North America. Only by fractionalizing the count, an author from Thailand is detected. However, his impact within the field is very modest, with only 107 citations compared to hundreds or thousands of citations of his peers. Second, the Western monocentric within the discipline seemingly derives from the close collaboration networks among European and North American top authors and institutions. When we plot the collaboration network of 50 most representative institutions, a close-knit scientific community formed by institutions within Europe and North America could be observed. Meanwhile, the collaboration network among 60 most representative authors illustrates "alliances" of top Western authors, or we may call "supreme groups". The close connection of Western authors and institutions might amplify their impact on entrepreneurial finance and simultaneously reinforce the influential power of the Western ideology. In contrast, less relevant authors tend to work alone or in a small group; hence their impact is much smaller than the large research groups. In such a Western-centric discipline, China has an impressive performance in terms of publications, but its impact is low compared to the Western countries. Given that entrepreneurial finance is becoming a global issue (Boyde 2015, Hruby 2019, Sindakis 2015, Vuong 2014), we would like to raise the concern of ideological homogeneity in the field of entrepreneurial finance.

To address the hindrances of Western ideological homogeneity, we will take China as an exemplary case. Bruton and Ahlstrom (2003) find that institutional forces make the venture capital industry in China significantly different from the West. Although the financing system in China sometimes functions similarly to Western countries (Guo and Jiang 2013), various studies reveal the inconsistent findings regarding the effects of venture capital in China and Western countries due to the environmental, institutional, and political differences (Ahlstrom et al. 2007, Fuller 2010, 
Wang and Wang 2011). In addition, there even exists the circumstance that despite the similar significant impact of entrepreneur's social capital ties on crowdfunding performance between China and the USA, the predictive power is stronger in China than the USA (Zheng et al. 2014).

In sum, we believe that there are no "one size fits all" theories, concepts, and frameworks that can explain the dynamics of entrepreneurial finance, especially when the concept was born in this place, but is used in another place with different socio-cultural, institutional, and financial contexts, which are strong predictors of entrepreneurship (Vuong 2016a, b). Given that the dominance of Western ideology in entrepreneurial finance may constraint researchers from non-Western countries to share different opinions and direct international research toward Western research orthodox, we believe that the economies around the world will take great benefits from a more ideologically diverse environment. In an ideological heterogeneity environment, a country might find the most appropriate ideology that is not only effective in promoting economic development but also receive less resistance from the institutional and socio-cultural filter process of that country. However, ideological diversity is very costly, especially for emerging countries, because it requires a strong scientific foundation and proactive attitudes from researchers, institutions, and governments (Vuong 2018, 2019).

Based on the co-occurrence analysis of the most 500 authors' keywords, we identify seven main research domains, including "venture capital", "crowdfunding", "SMEs finance", "social entrepreneurship finance", "financial risk", "microfinance", and "human-social-financial capital". Among the seven domains, there are still many rooms for further research in "venture capital" and "crowdfunding" domains. As these two domains are about the two most important financing methods of entrepreneurs, they have a substantive connection with other themes within the field, but the internal links have not been fully built up. The "social entrepreneurship finance" and "financial risk" are two well-developed domains but still need more studies linking them with other themes, such as "venture capital" and "crowdfunding". Given the collectivism nature in Asia, the "human-social-financial capital" is a potential domain for Asian researchers to create their own ideologies. For regions that lack access to the conventional banking system or obtain an inequality level, "microfinance" might be a good approach to start with. In addition, even though "microfinance" research theme is currently underdeveloped and unimportant among the field, its significance in entrepreneurial finance of non-Western and emerging countries is inevitable for poverty reduction, gender equality, and sustainable development. Thus, the theme can be developed into a major theme (or motor theme) based on non-Western ideologies, which generate more opinion heterogeneity in entrepreneurial finance discipline.

There are several limitations we acknowledge in our study. Despite the objectivity of using search terms to distinguish venture capital and entrepreneurial finance fields, there is a probability that several studies about venture capital that are related to entrepreneurial finance are missing. WoS search algorithm provides only results searched in most prominent sections of the article, but not the whole articles (e.g. title, abstract, keyword, etc.), so it fails to detect articles with deeper layers of meaning. The bibliometrics method helps develop a holistic and objective viewpoint on the studied field; nevertheless, key findings cannot be explained in detail, which requires the implementation of a qualitative review. In this study, we only use data from WoS database and do not consider articles not written in English and various forms of publication (etc. books, book 
sections, and proceeding papers), so there is a possibility of production bias, as some countries usually publish social science studies in the form of books, write a research paper in their own language, and publish in a local database, such as Japan (Nguyen et al. 2020). Last but not least, the findings in this study can only show the dominance of Western countries in terms of scientific production and international collaboration within the discipline, but not really an ideological homogeneity. Therefore, further studies employing Y-index, histography, co-citation, and qualitative analyses are recommended to further examine the Western ideological homogeneity. 


\section{Supplementary:}

Table S1: Top ten journals for scientific output during three periods in entrepreneurial finance discipline. This table provides the top ten journals for scientific production employing full counting in three periods: 1970-2000, 2001-2010, and 2011-2019. More details are discussed in sub-section 3.1.3.

\begin{tabular}{|c|c|c|c|c|c|c|}
\hline \multirow{2}{*}{ Rank } & \multicolumn{2}{|l|}{$1970-2000$} & \multicolumn{2}{|l|}{$2001-2010$} & \multicolumn{2}{|l|}{ 2011-2019 } \\
\hline & Journal & Article & Journal & Article & Journal & Article \\
\hline 1 & $\begin{array}{l}\text { Journal of Business } \\
\text { Venturing }\end{array}$ & 88 & Journal of Business Venturing & 67 & Small Business Economics & 151 \\
\hline 2 & $\begin{array}{l}\text { Small Business } \\
\text { Economics }\end{array}$ & 20 & Small Business Economics & 61 & Journal of Business Venturing & 96 \\
\hline 3 & $\begin{array}{l}\text { Harvard Business } \\
\text { Review }\end{array}$ & 14 & $\begin{array}{c}\text { Entrepreneurship Theory and } \\
\text { Practice }\end{array}$ & 32 & Sustainability & 81 \\
\hline 4 & $\begin{array}{c}\text { Journal of Small } \\
\text { Business Management }\end{array}$ & 9 & $\begin{array}{c}\text { Entrepreneurship and Regional } \\
\text { Development }\end{array}$ & 28 & Journal of Business Research & 69 \\
\hline 5 & World Development & 9 & Journal of Financial Economics & 22 & $\begin{array}{c}\text { Journal of Small Business } \\
\text { Management }\end{array}$ & 62 \\
\hline 6 & Technovation & 8 & Technovation & 21 & $\begin{array}{c}\text { Entrepreneurship Theory and } \\
\text { Practice }\end{array}$ & 61 \\
\hline 7 & Forbes & 6 & $\begin{array}{c}\text { Journal of Small Business } \\
\text { Management }\end{array}$ & 18 & Venture Capital & 61 \\
\hline 8 & $\begin{array}{c}\text { Review of Economic } \\
\text { Studies }\end{array}$ & 6 & Journal of Finance & 17 & $\begin{array}{c}\text { International Entrepreneurship and } \\
\text { Management Journal }\end{array}$ & 55 \\
\hline 9 & Scientist & 6 & Harvard Business Review & 16 & Research Policy & 49 \\
\hline
\end{tabular}




\begin{tabular}{|c|c|c|c|c|c|}
\hline 10 & Chimia & 5 & $\begin{array}{c}\text { International Journal of } \\
\text { Technology Management }\end{array}$ & 16 & $\begin{array}{c}\text { Technological Forecasting and } \\
\text { Social Change }\end{array}$ \\
\hline
\end{tabular}

Table S2: Top ten journals for scientific impact during three periods in entrepreneurial finance discipline. This table provides the top ten journals for scientific impact (measured by the GCS) in three periods: 1970-2000, 2001-2010, and 2011-2019. More details are discussed in sub-section 3.1.3.

\begin{tabular}{|c|c|c|c|c|c|c|}
\hline \multirow[b]{2}{*}{ Rank } & \multicolumn{2}{|l|}{$1970-2000$} & \multicolumn{2}{|l|}{$2001-2010$} & \multicolumn{2}{|l|}{ 2011-2019 } \\
\hline & Journal & $\begin{array}{c}\text { Total } \\
\text { citations }\end{array}$ & Journal & $\begin{array}{l}\text { Total } \\
\text { citations }\end{array}$ & Journal & $\begin{array}{c}\text { Total } \\
\text { citations }\end{array}$ \\
\hline 1 & $\begin{array}{l}\text { Journal of Business } \\
\text { Venturing }\end{array}$ & 15299 & $\begin{array}{l}\text { Journal of Business } \\
\text { Venturing }\end{array}$ & 7522 & Journal of Business Venturing & 4079 \\
\hline 2 & $\begin{array}{c}\text { Administrative } \\
\text { Science Quarterly }\end{array}$ & 1203 & Small Business Economics & 3275 & Small Business Economics & 2688 \\
\hline 3 & $\begin{array}{c}\text { Review of Economic } \\
\text { Studies }\end{array}$ & 1145 & Journal of Finance & 3243 & Entrepreneurship Theory and Practice & 1685 \\
\hline 4 & $\begin{array}{l}\text { Quarterly Journal of } \\
\text { Economics }\end{array}$ & 1113 & $\begin{array}{c}\text { Strategic Management } \\
\text { Journal }\end{array}$ & 2821 & Research Policy & 1417 \\
\hline 5 & $\begin{array}{l}\text { Small Business } \\
\text { Economics }\end{array}$ & 1087 & $\begin{array}{c}\text { Journal of Financial } \\
\text { Economics }\end{array}$ & 2734 & Strategic Management Journal & 870 \\
\hline
\end{tabular}




\begin{tabular}{|c|c|c|c|c|c|c|}
\hline 6 & $\begin{array}{c}\text { Academy of } \\
\text { Management Journal }\end{array}$ & 1036 & $\begin{array}{c}\text { Entrepreneurship Theory } \\
\text { and Practice }\end{array}$ & 2732 & Journal of Business Research \\
\hline 7 & $\begin{array}{c}\text { Review of Financial } \\
\text { Studies }\end{array}$ & 809 & Research Policy & 2327 & $\begin{array}{c}\text { Journal of Small Business } \\
\text { Management }\end{array}$ \\
\hline 8 & $\begin{array}{c}\text { Harvard Business } \\
\text { Review }\end{array}$ & 803 & $\begin{array}{c}\text { Entrepreneurship and } \\
\text { Regional Development }\end{array}$ & 1703 & $\begin{array}{c}\text { Entrepreneurship and Regional } \\
\text { Development }\end{array}$ \\
\hline 9 & Journal of Finance & 690 & $\begin{array}{c}\text { Management Science } \\
560\end{array}$ & 1433 & $\begin{array}{c}\text { International Small Business Journal- } \\
\text { Researching Entrepreneurship }\end{array}$ \\
\hline 10 & $\begin{array}{c}\text { Strategic } \\
\text { Management Journal }\end{array}$ & 651 & $\begin{array}{c}\text { Academy of Management } \\
\text { Journal }\end{array}$ & 1275 & Journal of Business Ethics \\
\hline
\end{tabular}


Author Contributions: Conceptualization, M.-H.N. and Q.-H.V.; methodology, M.-H.N., T.T.H.N, and Q.-Y.T.N; software, M.-H.N; validation, Q.-H.V.; formal analysis, M.-H.N and T.T.H.N.; investigation, T.T.H.N. and Q.-Y.T.N; resources, Q.-Y.T.N and T.-H.P; data curation, M.-H.N and T.T.H.N; writing - original draft preparation, M.-H.N, T.T.H.N, T.-H.P, Q.-Y.T.N, and Q.-H.V.; writing — review and editing, M.-H.N, T.T.H.N, and Q.-H.V ; visualization, M.-H.N; supervision, Q.-H.V.; project administration, M.-H.N.; funding acquisition, Q.-H.V. All authors have read and agreed to the published version of the manuscript.

Funding: Please add: This research received no external funding

\section{Acknowledgments:}

Conflicts of Interest: The authors declare no conflict of interest.

\section{References}

Adomako, Samuel. 2018. The moderating effects of adaptive and intellectual resource capabilities on the relationship between entrepreneurial orientation and financial performance. International Journal of Innovation Management 22: 1850026.

Ahlstrom, David, Garry D Bruton, and Kuang S Yeh. 2007. Venture capital in China: Past, present, and future. Asia Pacific Journal of Management 24: 247-68.

Alawattage, Chandana, Cameron Graham, and Danture Wickramasinghe. 2019. Microaccountability and biopolitics: Microfinance in a Sri Lankan village. Accounting, Organizations and Society 72: 38-60.

Allub, Lian, and Andrés Erosa Etchebehere. 2014. Financial frictions, occupational choice and economic inequality.

Aparicio, Gloria, Txomin Iturralde, and Amaia Maseda. 2019. Conceptual structure and perspectives on Entrepreneurship education research: A bibliometric review. European Research on Management and Business Economics 25: 105-13.

Aria, Massimo, and Corrado Cuccurullo. 2017. bibliometrix: An R-tool for comprehensive science mapping analysis. Journal of Informetrics 11: 959-75.

Atkeson, Lonna Rae, and Andrew J Taylor. 2019. Partisan Affiliation in Political Science: Insights from Florida and North Carolina. PS: Political Science \& Politics 52: 706-10.

Baker, H Kent, Satish Kumar, and Nitesh Pandey. 2019. Thirty years of the Global Finance Journal: A bibliometric analysis. Global Finance Journal: 100492.

Bellavitis, Cristiano, Igor Filatotchev, Dzidziso Samuel Kamuriwo, and Tom Vanacker. 2017. "Entrepreneurial finance: new frontiers of research and practice: Editorial for the special issue Embracing entrepreneurial funding innovations." Taylor \& Francis.

Belleflamme, Paul, Thomas Lambert, and Armin Schwienbacher. 2014. Crowdfunding: Tapping the right crowd. Journal of business venturing 29: 585-609. 
Boudreaux, Christopher J, and Boris Nikolaev. 2019. Capital is not enough: opportunity entrepreneurship and formal institutions. Small Business Economics 53: 709-38.

Boyde, E. 2015. The rise of the Asian entrepreneur. Available online: https://www.ft.com/content/41b9ac52-efd5-11e4-ab73-00144feab7de (accessed on 13/03).

Bruton, Garry D, and David Ahlstrom. 2003. An institutional view of China's venture capital industry: Explaining the differences between China and the West. Journal of business venturing 18: 233-59.

Callon, Michel, Jean Pierre Courtial, and Francoise Laville. 1991. Co-word analysis as a tool for describing the network of interactions between basic and technological research: The case of polymer chemsitry. Scientometrics 22: 155-205.

Campbell, James E. 2019. The Trust Is Gone: What Ideological Orthodoxy Costs Political Science. PS: Political Science \& Politics 52: 715-19.

Chemmanur, Thomas J, and Paolo Fulghieri. 2014. Entrepreneurial finance and innovation: An introduction and agenda for future research. The Review of Financial Studies 27: 1-19.

Cheng, Cheng, Yangbin Sun, Yaqin Su, and Shenggang Yang. 2019. Venture capital, innovation, and growth: evidence from Chinese metropolitan data. Applied Economics Letters 26: 549-53.

Clarivate Analytics. 2020. Web of Science: Confident research begins here. Available online: https://clarivate.com/webofsciencegroup/solutions/web-of-science/ (accessed on 13/03).

Cobo, Manuel J, Antonio Gabriel López-Herrera, Enrique Herrera-Viedma, and Francisco Herrera. 2011a. An approach for detecting, quantifying, and visualizing the evolution of a research field: A practical application to the fuzzy sets theory field. Journal of Informetrics 5: 146-66.

Cobo, Manuel J, Antonio Gabriel López-Herrera, Enrique Herrera-Viedma, and Francisco Herrera. 2011b. Science mapping software tools: Review, analysis, and cooperative study among tools. Journal of the American Society for Information Science and Technology 62: 1382-402.

Cobo, Manuel J, Miguel-Ángel Martínez, María Gutiérrez-Salcedo, Hamido Fujita, and Enrique Herrera-Viedma. 2015. 25 years at Knowledge-based systems: A bibliometric analysis. Knowledge-based systems 80: 3-13.

Cooper, Arnold C, F Javier Gimeno-Gascon, and Carolyn Y Woo. 1994. Initial human and financial capital as predictors of new venture performance. Journal of business venturing 9: 37195.

Crew, B. 2019. The top 10 countries in research collaboration. Available online: https://www.natureindex.com/news-blog/data-visualization-top-ten-countries-researchcollaboration (accessed on 13/03).

Cuccurullo, Corrado, Massimo Aria, and Fabrizia Sarto. 2016. Foundations and trends in performance management. A twenty-five years bibliometric analysis in business and public administration domains. Scientometrics 108: 595-611. 
Cumming, Douglas, and Sofia Johan. 2017. The problems with and promise of entrepreneurial finance. Strategic Entrepreneurship Journal 11: 357-70.

Cumming, Douglas, and Alexander Peter Groh. 2018. Entrepreneurial finance: Unifying themes and future directions. Journal of corporate finance 50: 538-55.

Cumming, Douglas, Marc Deloof, Sophie Manigart, and Mike Wright. 2019a. New directions in entrepreneurial finance. Journal of Banking \& Finance 100: 252-60.

Cumming, Douglas, Michele Meoli, and Silvio Vismara. 2019b. Investors' choices between cash and voting rights: Evidence from dual-class equity crowdfunding. Research Policy 48: 103740.

Denis, David J. 2004. Entrepreneurial finance: an overview of the issues and evidence. Journal of corporate finance 10: 301-26.

Dhahri, Sabrine, and Anis Omri. 2018. Entrepreneurship contribution to the three pillars of sustainable development: What does the evidence really say? World Development 106: 64-77.

Dilger, Robert Jay. 2013. Small business administration and job creation.

Donkor, Jacob, George Nana Agyekum Donkor, Collins Kankam-Kwarteng, and Eunice Aidoo. 2018. Innovative capability, strategic goals and financial performance of SMEs in Ghana. Asia Pacific Journal of Innovation and Entrepreneurship.

Fan, Zhaobin, and Ruohan Zhang. 2017. Financial inclusion, entry barriers, and entrepreneurship: evidence from China. Sustainability 9: 203.

Farrington, Shelley, Elmarie Venter, and Bianca Richardson. 2018. The influence of selected marketing and branding practices on the financial performance of family SMEs. Southern African Business Review 22.

Foster, Joshua. 2019. Thank you for being a friend: The roles of strong and weak social network ties in attracting backers to crowdfunded campaigns. Information Economics and Policy 49: 100832 .

Fraser, Stuart, Sumon Kumar Bhaumik, and Mike Wright. 2015. What do we know about entrepreneurial finance and its relationship with growth? International Small Business Journal 33: 70-88.

Fuller, Douglas B. 2010. How law, politics and transnational networks affect technology entrepreneurship: Explaining divergent venture capital investing strategies in China. Asia Pacific Journal of Management 27: 445-59.

Garfield, Eugene, Irving H Sher, and Richard J Torpie. 1964. The use of citation data in writing the history of science.

Garfield, Eugene, Alexander I Pudovkin, and VS Istomin. 2002. Algorithmic citation-linked historiography-Mapping the literature of science. Proceedings of the American Society for Information Science and Technology 39: 14-24. 
Garfield, Eugene, S Paris, and Wolfgang G Stock. 2006. HistCiteTM: A software tool for informetric analysis of citation linkage. Information Wissenschaft und Praxis 57: 391.

Gauffriau, Marianne. 2017. A categorization of arguments for counting methods for publication and citation indicators. Journal of Informetrics 11: 672-84.

Gewin, Virginia. 2014. Interdisciplinary research: break out. Nature 511: 371-73.

Giang, Mai Huong, Tran Dang Xuan, Bui Huy Trung, Mai Thanh Que, and Yuichiro Yoshida. 2018. Impact of investment climate on total factor productivity of manufacturing firms in Vietnam. Sustainability 10: 4815.

Gomezel, Alenka Slavec, and Kaja Rangus. 2018. An exploration of an entrepreneur's open innovation mindset in an emerging country. Management Decision.

Gompers, P A , and Josh Lerner. 1994. "A Note on the Venture Capital Industry."

Gompers, Paul, and Josh Lerner. 2001. The venture capital revolution. Journal of economic perspectives 15: 145-68.

Gonzalez-Perez, Maria Alejandra, Juan Velez-Ocampo, and Carolina Herrera-Cano. 2018. Entrepreneurs' Features Affecting the Internationalisation of Service SMEs. Entrepreneurial Business and Economics Review 6: 9-28.

Gray, Brendan, Jodyanne Kirkwood, Mitra Etemaddar, and Ella Monahan. 2018. Sustainable business models for community-based enterprises in Samoa and Tonga. Small Enterprise Research 25: 99-113.

$\mathrm{Gu}$, Wentao, and Xuzheng Qian. 2019. Does venture capital foster entrepreneurship in an emerging market? Journal of Business Research 101: 803-10.

Guo, Di, and Kun Jiang. 2013. Venture capital investment and the performance of entrepreneurial firms: Evidence from China. Journal of corporate finance 22: 375-95.

Guzman, Jorge, and Aleksandra Olenka Kacperczyk. 2019. Gender gap in entrepreneurship. Research Policy 48: 1666-80.

$\mathrm{Ha}$, Phuoc Vu, and Michael Frömmel. 2019. Social Capital, Credit Choices and Growth in Vietnamese Household Businesses. Journal of Developmental Entrepreneurship 24: 1950017.

Haustein, Stefanie, and Vincent Larivière. 2015. The use of bibliometrics for assessing research: Possibilities, limitations and adverse effects. In Incentives and performance. Edited by I M Welpe, J Wollersheim, S Ringelhan and M Osterloh. Springer, pp. 121-39.

Hellmann, Thomas, and Manju Puri. 2000. The interaction between product market and financing strategy: The role of venture capital. The Review of Financial Studies 13: 959-84.

- 2002. Venture capital and the professionalization of start-up firms: Empirical evidence. The journal of finance 57: 169-97. 
Hervé, Fabrice, Elodie Manthé, Aurélie Sannajust, and Armin Schwienbacher. 2019. Determinants of individual investment decisions in investment-based crowdfunding. Journal of Business Finance \& Accounting 46: 762-83.

Hruby, A. 2019. Entrepreneurship funds in Africa: Distinguishing the good from the bad. Available online: https://theconversation.com/entrepreneurship-funds-in-africa-distinguishingthe-good-from-the-bad-115927 (accessed on 13/03).

Hsu, David H. 2004. What do entrepreneurs pay for venture capital affiliation? The journal of finance 59: 1805-44.

Hussain, Javed, Samia Mahmood, and Jonathan Scott. 2019. Gender, Microcredit and Poverty Alleviation in a Developing Country: The Case of Women Entrepreneurs in Pakistan. Journal of International Development 31: 247-70.

Huynh, Thanh. 2016. Early-stage fundraising of university spin-offs: a study through demand-site perspectives. Venture Capital 18: 345-67.

2019. What makes external supporters engage in university spin-off seed investments: Entrepreneurs' capabilities or social networks? International Journal of Innovation Management 23: 1950010.

Jin, Byoungho, Sojin Jung, and So Won Jeong. 2018. Dimensional effects of Korean SME's entrepreneurial orientation on internationalization and performance: the mediating role of marketing capability. International Entrepreneurship and Management Journal 14: 195-215.

Kaplan, Steven N, and Per Strömberg. 2003. Financial contracting theory meets the real world: An empirical analysis of venture capital contracts. The review of economic studies 70: 281-315.

Kraus, Sascha, Matthias Filser, Michele O'Dwyer, and Eleanor Shaw. 2014. Social entrepreneurship: an exploratory citation analysis. Review of Managerial Science 8: 275-92.

Laurell, Christofer, Christian Sandström, and Yuliani Suseno. 2019. Assessing the interplay between crowdfunding and sustainability in social media. Technological Forecasting and Social Change 141: 117-27.

Lindsey, Duncan. 1980. Production and citation measures in the sociology of science: The problem of multiple authorship. Social Studies of Science 10: 145-62.

Macht, Stephanie, and Geoffrey Chapman. 2019. Getting more than money through online crowdfunding. Asia-Pacific Journal of Business Administration.

Madrazo-Lemarroy, Pilar, Karla Barajas-Portas, and Maria Elena Labastida Tovar. 2019. Analyzing campaign's outcome in reward-based crowdfunding. Internet Research.

Martínez-Climent, Carla, Ricardo Costa-Climent, and Pejvak Oghazi. 2019. Sustainable Financing through Crowdfunding. Sustainability 11: 934.

Megginson, William. 2002. Towards a global model of venture capital? Forthcoming. Journal of Applied Corporate Finance. 
Megginson, William L, Antonio Meles, Gabriele Sampagnaro, and Vincenzo Verdoliva. 2019. Financial distress risk in initial public offerings: how much do venture capitalists matter? Journal of corporate finance 59: 10-30.

Miller, Andrea, Shane Scahill, and Lorraine Warren. 2019. Investor motivations of a New Zealand biopharma start-up: Angels and crowdfunders. The International Journal of Entrepreneurship and Innovation 20: 252-62.

Moed, Henk F. 2006. Citation analysis in research evaluation. Vol. 9, Springer Science \& Business Media.

Mollick, Ethan. 2014. The dynamics of crowdfunding: An exploratory study. Journal of business venturing 29: 1-16.

Mongeon, Philippe, and Adèle Paul-Hus. 2016. The journal coverage of Web of Science and Scopus: a comparative analysis. Scientometrics 106: 213-28.

Napier, Nancy K, Dang Vu, and Quan Hoang Vuong. 2012. It takes two to tango: Entrepreneurship and creativity in troubled times_-Vietnam 2012. Sociology Study 2: 662-74.

Nature Index. 2019. A guide to the Nature Index. Available online: https://www.nature.com/articles/d41586-019-01443-9 (accessed on 04/05).

Nescolarde-Selva, Josué Antonio, José-Luis Usó-Doménech, and Hugh Gash. 2017. What Are Ideological Systems? Systems 5: 21.

Nguyen, Minh-Hoang, Manh-Tung Ho, Viet-Phuong La, Quynh-Yen Thi Nguyen, Manh-Toan Ho, Thu-Trang Vuong, Tam-Tri Le, Manh-Cuong Nguyen, and Quan-Hoang Vuong. 2020. A Scientometric Study on Depression among University Students in East Asia: Research

Nigri, Giorgia, and Mara Del Baldo. 2018. Sustainability Reporting and Performance Measurement Systems: How do Small-and Medium-Sized Benefit Corporations Manage Integration? Sustainability 10: 4499.

OECD. 2017. Entrepreneurship at a Glance 2017. Paris: OECD Publishing.

- 2019. OECD SME and Entrepreneurship Outlook 2019. Paris: OECD Publishing.

Padilla-Ospina, Ana Milena, Javier Enrique Medina-Vásquez, and Jorge Alberto Rivera-Godoy. 2018. Financing innovation: A bibliometric analysis of the field. Journal of Business \& Finance Librarianship 23: 63-102.

Paré, Jean-Louis, Jean Rédis, and Jean-Michel Sahut. 2009. The development of entrepreneurial finance research. International Journal of Business 14: 283.

Peredo, Ana Maria, and Murdith McLean. 2006. Social entrepreneurship: A critical review of the concept. Journal of world business 41: 56-65. 
Perianes-Rodriguez, Antonio, Ludo Waltman, and Nees Jan Van Eck. 2016. Constructing bibliometric networks: A comparison between full and fractional counting. Journal of Informetrics 10: 1178-95.

Price, Sophia. 2019. The risks and incentives of disciplinary neoliberal feminism: the case of microfinance. International Feminist Journal of Politics 21: 67-88.

platforms do? A comparison between investment-based platforms in Europe. Eurasian Business Review 8: 93-118.

Santos, Roberto S, and Lingling Qin. 2019. Risk Capital and Emerging Technologies: Innovation and Investment Patterns Based on Artificial Intelligence Patent Data Analysis. Journal of Risk and Financial Management 12: 189.

Satar, Mir Shahid, and Shibu John. 2016. A conceptual model of critical success factors for Indian social enterprises. World Journal of Entrepreneurship, Management and Sustainable Development 12: $113-38$.

Scherer, Frederic M. 1991. Changing perspectives on the firm size problem. In Innovation and technological change: An international comparison. Edited by Z J Ács and D B Audretsch. University of Michigan Press, pp. 24-38.

Scutariu, Adrian-Liviu, Carmen Nastase, and Mihai Popescu. 2016. Perspectives of sustainable development of tourism in the North-East Region of Romania. Sustainability 9: 1-14.

Shane, Scott, and Daniel Cable. 2002. Network ties, reputation, and the financing of new ventures. Management science 48: 364-81.

Signori, Andrea, and Silvio Vismara. 2018. Does success bring success? The post-offering lives of equity-crowdfunded firms. Journal of corporate finance 50: 575-91.

Sindakis, Stavros. 2015. The Entrepreneurial Rise in Southeast Asia: The Quadruple Helix Influence on Technological Innovation. Springer.

Stef, Nicolae, and Sami Ben Jabeur. 2018. The Bankruptcy Prediction Power of New Entrants. International Journal of the Economics of Business 25: 421-40.

Stuart, Toby E, Ha Hoang, and Ralph C Hybels. 1999. Interorganizational endorsements and the performance of entrepreneurial ventures. Administrative science quarterly 44: 315-49.

Tasavori, Misagh, Pervez N Ghauri, and Reza Zaefarian. 2016. Entering the base of the pyramid market in India. International Marketing Review 33: 555-79.

The CWTS Leiden Ranking. 2019. Indicators. Available online: https://www.leidenranking.com/information/indicators\#collaboration-indicators (accessed on 05/04).

Usman, Sardar Muhammad, Farasat Ali Shah Bukhari, Muhammad Usman, Daniel Badulescu, and Muhammad Safdar Sial. 2019. Does the role of media and founder's past success mitigate the 
problem of information asymmetry? Evidence from a UK crowdfunding platform. Sustainability 11: 692 .

Vallaster, Christine, Sascha Kraus, José M Merigó Lindahl, and Annika Nielsen. 2019. Ethics and entrepreneurship: A bibliometric study and literature review. Journal of Business Research 99: 226-37.

Verma, Abhiruchi Singh. 2017. Jugaad Entrepreneurship: A Cross Between Street and Social Entrepreneurship. JIMS8M: The Journal of Indian Management \& Strategy 22: 60-64.

Vismara, Silvio. 2016. Equity retention and social network theory in equity crowdfunding. Small Business Economics 46: 579-90.

- 2019. Sustainability in equity crowdfunding. Technological Forecasting and Social Change 141: 98-106.

Vu, Dang Le Nguyen, Nancy K Napier, and Vuong Quan Hoang. Year. Entrepreneurship and creativity in transition turmoil: the case of Vietnam. Paper presented at the Proceedings of the International Conference on Management, Leadership and Governance-ICMLG 2013.

Vuong, Quan-Hoang. 2018. The (ir) rational consideration of the cost of science in transition economies. Nature Human Behaviour 2: 5-5.

. 2019. Breaking barriers in publishing demands a proactive attitude. Nature Human Behaviour 3: 1034-34.

Vuong, Quan Hoang, Dam Van Nhue, Daniel Van Houtte, and Tri Dung Tran. 2011. The entrepreneurial facets as precursor to Vietnam's economic renovation in 1986. The IUP Journal of Entrepreneurship Development 8: 6-47.

Vuong, Quan Hoang. 2014. Managers and Management in Vietnam: 25 Years of Economic Renovation (Doi Moi). Pacific Affairs 87: 378-80.

. 2016a. Survey data on entrepreneurs' subjective plan and perceptions of the likelihood of success. Data in brief 6: 858-64.

- 2016b. Impacts of geographical locations and sociocultural traits on the Vietnamese entrepreneurship. SpringerPlus 5: 1189.

Vuong, Quan Hoang, Viet Phuong La, Thu Trang Vuong, Phuong Hanh Hoang, Manh Toan Ho, Manh Tung Ho, and Hong Kong To Nguyen. 2020. Multi-faceted insights of entrepreneurship facing a fast-growing economy: A literature review. $3: 25$. https://doi.org/10.1515/openec-20200002 .

Wang, Lanfang, and Susheng Wang. 2011. Cross-border venture capital performance: Evidence from China. Pacific-Basin Finance Journal 19: 71-97.

Weingart, Peter. 2005. Impact of bibliometrics upon the science system: Inadvertent consequences? Scientometrics 62: 117-31. 
Wojcieszak, Magdalena. 2010. 'Don't talk to me': effects of ideologically homogeneous online groups and politically dissimilar offline ties on extremism. New Media \& Society 12: 637-55.

Xu, Xinhan, Xiangfeng Chen, Fu Jia, Steve Brown, Yu Gong, and Yifan Xu. 2018. Supply chain finance: A systematic literature review and bibliometric analysis. International Journal of Production Economics 204: 160-73.

Zahra, Shaker A. 1991. Predictors and financial outcomes of corporate entrepreneurship: An exploratory study. Journal of business venturing 6: 259-85.

1993. Environment, corporate entrepreneurship, and financial performance: A taxonomic approach. Journal of business venturing 8: 319-40.

Zahra, Shaker A, and Jeffrey G Covin. 1995. Contextual influences on the corporate entrepreneurship-performance relationship: A longitudinal analysis. Journal of business venturing 10: 43-58.

Zhang, Dayong, Zhiwei Zhang, and Shunsuke Managi. 2019. A bibliometric analysis on green finance: Current status, development, and future directions. Finance Research Letters 29: 425-30.

Zhang, Juan, Qi Yu, Fashan Zheng, Chao Long, Zuxun Lu, and Zhiguang Duan. 2016. Comparing keywords plus of WOS and author keywords: A case study of patient adherence research. Journal of the Association for Information Science and Technology 67: 967-72.

Zheng, Haichao, Dahui Li, Jing Wu, and Yun Xu. 2014. The role of multidimensional social capital in crowdfunding: A comparative study in China and US. Information \& Management 51: 488-96.

Zupic, Ivan, and Tomaž Čater. 2015. Bibliometric methods in management and organization. Organizational Research Methods 18: 429-72. 